\title{
Patterns of hominin occupation and cultural diversity across the Gebel Akhdar of Northern Libya over the last $200 \mathrm{kyr}$
}

Book or Report Section

Accepted Version

Jones, S., Antoniadou, A., Barton, H., Drake, N., Farr, L., Hunt, C., Inglis, R., Reynolds, T., White, K. and Barker, G. (2016) Patterns of hominin occupation and cultural diversity across the Gebel Akhdar of Northern Libya over the last 200 kyr. In: Jones, S. C. and Stewart, B. A. (eds.) Africa from MIS 6-2: Population Dynamics and Paleoenvironments. Vertebrate Paleobiology and Paleoanthropology. Springer, Dordrecht, pp. 77-99. ISBN 9789401775205 doi: https://doi.org/10.1007/97894-017-7520-5_5 Available at https://centaur.reading.ac.uk/58448/

It is advisable to refer to the publisher's version if you intend to cite from the work. See Guidance on citing.

To link to this article DOI: http://dx.doi.org/10.1007/978-94-017-7520-5_5

Publisher: Springer

All outputs in CentAUR are protected by Intellectual Property Rights law, including copyright law. Copyright and IPR is retained by the creators or other copyright holders. Terms and conditions for use of this material are defined in the End User Agreement. 


\section{www.reading.ac.uk/centaur}

\section{CentAUR}

Central Archive at the University of Reading

Reading's research outputs online 
Patterns of Hominin Occupation and Cultural Diversity across the Gebel Akhdar of Northern Libya over the Last $\sim 200$ kyr

Sacha Jones (corresponding author)

McDonald Institute for Archaeological Research, University of Cambridge, Downing Street, Cambridge, CB2 3ER, United Kingdom.

Email: scj23@cam.ac.uk

Annita Antoniadou

School of Geography, Archaeology and Palaeoecology, Queen's University, Belfast, Northern Ireland, BT7 1NN, United Kingdom.

Huw Barton

School of Archaeology and Ancient History, University of Leicester, Leicester, LE1 7RH, United Kingdom.

Nick Drake

Department of Geography, King's College London, London WC2R 2LS, United Kingdom.

Lucy Farr

McDonald Institute for Archaeological Research, University of Cambridge, Downing Street, Cambridge, CB2 3ER, United Kingdom.

Chris Hunt

School of Natural Sciences and Psychology, Liverpool John Moores University, Byrom Street, Liverpool, L3 3AF, United Kingdom. 
Robyn Inglis

Department of Archaeology, University of York, The King's Manor, York, YO1 7EP, United Kingdom.

Tim Reynolds

Department of History, Classics \& Archaeology, Birkbeck, University of London, Russell Square, Bloomsbury, London WC1B 5DQ, United Kingdom.

Kevin White

Department of Geography, University of Reading, Whiteknights, Reading, RG6 6AB, United Kingdom.

Graeme Barker

McDonald Institute for Archaeological Research, University of Cambridge, Downing Street, Cambridge, CB2 3ER, United Kingdom. 


\begin{abstract}
Excavations at Haua Fteah cave in Cyrenaica, Libya, have revealed a cultural sequence that may span the last glacial-interglacial-glacial cycle. The TRANS-NAP project has been reexcavating Haua Fteah and conducting geoarchaeological survey of an ecologically diverse landscape that includes the fertile Gebel Akhdar and littoral, pre-desert and desert biomes. A major aim of this project is to characterize cultural and environmental changes across the region and correlate the surface archaeology with that from Haua Fteah. To date, 181 sites have been recorded, ranging from the Middle Stone Age (MSA) to Late Stone Age (LSA). Their geographic distribution suggests temporal variation in patterns of hominin habitat preference, with significantly more LSA than MSA sites at higher elevations. The surface archaeology also points to substantial spatio-temporal technological variation within the MSA. These patterns may be explained by both paleoenvironmental change and paleodemographic shifts in the region, resulting in a variety of hominin adaptive responses.
\end{abstract}

Keywords: Cyrenaica, Middle Stone Age, Late Stone Age, Haua Fteah, Mediterranean littoral, Sahara, dispersal routes

Running head: Human Occupation across the Gebel Akhdar 


\section{Introduction}

North Africa during the last glacial-interglacial-glacial cycle witnessed a number of complex demographic and behavioral changes. The oldest Homo sapiens fossils in North Africa, from Jebel Irhoud in Morocco, currently point to colonization of the region during MIS 6 (Hublin 2001: 110; Smith et al. 2007; Stringer and Barton 2008; Balter 2011; Hublin and McPherron 2012). The first MSA technologies in North Africa also date to MIS 6 and to even earlier in MIS 7 (e.g., McBrearty and Brooks 2000; Garcea 2010a, 2012; Hawkins 2012), where the latter raises the question of which hominin populations and species were responsible for the early MSA across the region. From MIS 6 onwards, other key demographic and behavioral processes occurred in North Africa. For example, modern humans are argued to have dispersed across the Sahara and out of Africa during the climatic optimum of MIS 5e (Drake et al. 2008, 2011; Osborne et al. 2008; Hublin and Klein 2011). It was during MIS 5 that classic markers of symbolic behavior or "behavioral modernity" (e.g., shell beads, ochre use) start appearing in MIS 5 Aterian contexts, rivaling in nature and age similar cultural material from southern Africa (McBrearty and Brooks 2000; Bouzouggar et al. 2007; Barton et al. 2009; d'Errico et al. 2009). From late MIS 4 until the Holocene, a paucity of archaeological evidence from the Sahara suggests that populations became confined to coastal areas as the Sahara became increasingly arid (Cremaschi et al. 1998; Ambrose 1998; Barham and Mitchell 2008: 265). Yet, it is questionable that the Sahara was uninhabitable throughout this period, as suggested by recent evidence for pluvial episodes across the Sahara from MIS 4-2, albeit variable in timing, location and frequency (Smith 2012). Evidence for past water sources derived from aquifer-fed artesian springs and dating to MIS 4 and MIS 2 in the Kharga Oasis further point to greater water availability than perhaps previously assumed (Blackwell et al. 2012). Using the coastline in mid-MIS 3, populations are argued to have dispersed into North Africa from southwest Asia (McBurney 1967; Olivieri et al. 2006; Pereira et al. 2010). 
Possible markers of this include the appearance of early LSA ("Upper Paleolithic" or "Dabban") industries restricted mainly to northern Cyrenaica in Libya (McBurney and Hey 1955; McBurney 1967), although this may have been an autochthonous development (e.g., Iovita 2009, Garcea 2010b, 2010c). Few comparable early LSA sites are known from the Nile Valley (Vermeersch 2010), northeast Libya (Barich et al. 2006; Garcea and Giraudi 2006) or the Maghreb (Barton et al. 2007). At the end of this period, around the time of the Last Glacial Maximum (LGM), an explosion of backed bladelet industries appear in archaeological contexts across North Africa, clearly marking a change in the region's population dynamics (e.g., Close 2002).

These broad-scale changes from MIS 6-2 are only highlights of what would have been a far more complex period in recent human evolution, the details of which are becoming apparent only recently as North Africa gains more prominent status in paleoanthropological debates (e.g., Stringer and Barton 2008; Balter 2011; Hublin and McPherron 2012). Focusing on this critical period in recent human evolution, this study explores new archaeological evidence from northern Cyrenaica in Libya and addresses several key questions relating to past behaviors and population dynamics. For example, what were the relationships between changing resource distribution (e.g., water, plants, animals) from MIS 6-2, and raw material location, patterns of occupation and behavior during the MSA and LSA? As this study demonstrates that the MSA of the region, as with the rest of North Africa (Van Peer this volume), exhibits substantial technological variability, to what extent was this due to climate change and consequential demographic changes, and to what extent was it a result of behavioral adaptation of pre-existing populations to habitat and societal changes? Finally, MIS 6-2 was characteristically a period of modern human dispersals within Africa and beyond, yet at various points in time certain geographic regions (e.g., the Sahara) were barriers to population movements. When and how were demographic connections most 
plausible between northern Cyrenaica and regions beyond during this period? Furthermore, what was the degree of population isolation and what were the possible cultural manifestations of this? The evidence presented in this chapter, albeit hindered by limited fossil evidence and a lack of chronometric dates for the surface archaeology, goes some way towards answering these questions. These issues, however, continue to form part of the research agenda of the five-year ERC-funded TRANS-NAP project (Cultural Transformations and Environmental Transitions in North African Prehistory) of which this study is a part.

The TRANS-NAP project began in 2009 and one of its key aims is to characterize the cultural and environmental changes that occurred across an ecologically diverse North African landscape over the last $200 \mathrm{kyr}$, from the earliest MSA to the transition from hunting and gathering subsistence strategies to Neolithic farming. The project's study region is centered on the Gebel Akhdar ("Green Mountain"), an area of relatively high rainfall that forms a fertile zone within an otherwise arid east-west belt stretching from the eastern edge of the Maghreb to the Nile Valley, with the Sahara Desert lying directly to the south. The project's $\sim 150$ by $150 \mathrm{~km}$ study region traverses four biomes; from north to south these are: the littoral, upland (Gebel Akhdar), pre-desert and desert zones. Of particular interest is the relationship between climatic and environmental fluctuations, and changing human behaviors and population histories from the end of the Middle Pleistocene to the Holocene. This involves the use of archaeological and multi-proxy environmental data from multiple sites to: (1) reconstruct past paleoenvironments in the region over the last $\sim 200 \mathrm{kyr}$; (2) determine when and how $H$. sapiens colonized the region; (3) establish if certain behaviors enabled successful colonization by $H$. sapiens; and (4) ascertain if occupation was continuous through glacial periods and if the Gebel Akhdar may have acted as a refugium. These issues are being addressed through reinvestigation of Haua Fteah, a cave first excavated in the 1950s 
(McBurney 1967), and geoarchaeological survey of the four biomes within the study region. This chapter concentrates on the results of these geoarchaeological surveys, where patterns of occupation and changing technologies across the four biomes during the MSA and LSA are described and interpreted with respect to spatio-temporal changes in hominin adaptive behaviors. Additional evidence is drawn upon to posit theories about past population dynamics in northern Cyrenaica as well as connections with regions beyond from MIS 6-2.

\section{Geoarchaeological Surveys in the TRANS-NAP Project Study Region}

Previous geoarchaeological surveys in northern Cyrenaica concentrated on the coast and its immediate hinterland (Watson 1949; McBurney and Hey 1955; McBurney 1947, 1967, 1968; Hey 1968; Barker et al. 2007, 2008), but did not venture southwards across the Gebel Akhdar and into the arid zones. McBurney and Hey (1955) pioneered this research, reporting evidence from several open-air and cave sites. Typical MSA lithic types (referred to as "Middle Palaeolithic" or "Levalloiso-Mousterian") were recovered from raised beach deposits (e.g., at Wadi Haula, El Atrun and Ras Aamer). Other key finds from Wadi Sleib, near Tocra, include discoidal and flake-blade cores as well as a rare bifacial tool (a possible handaxe). They report more extensive investigations at one open-air site (Hajj Creiem) and two cave sites (Hagfet ed Dabba and Hagfet et Tera). Hajj Creiem, in Wadi Derna, produced in situ MSA lithics (e.g., Levallois cores, points and scrapers) and excavations at Hagfet ed Dabba, in the Wadi Kuf, produced large collections of fauna and blade-based assemblages. The latter represents the type-site of the "Upper Paleolithic" of the region, termed the "Dabban". Excavations at Hagfet et Tera, near Benghazi, produced some MSA but predominantly LSA (“Oranian”) artifacts (McBurney and Hey 1955). An Aterian presence in northern Cyrenaica is not compelling, being weakly represented at Hagfet et Tera, Ras Aamer and Haua Fteah (McBurney and Hey 1955; McBurney 1967: 129; Reynolds 2013). 
Haua Fteah, a $\sim 80$ m-wide and 20 m-high cave, was first excavated by McBurney and colleagues over three field seasons in the 1950s (McBurney 1967). The cave's deposits were excavated as a series of trenches to a depth of $14 \mathrm{~m}$, revealing tens of thousands of lithics and faunal fragments, including two H. sapiens mandibles in MSA ("LevalloisoMousterian") levels. Excavations produced a complex cultural succession, from the idiosyncratic and inappropriately named "pre-Aurignacian" (an early MSA lithic collection from the cave's deepest sediments) to the Neolithic and Historic periods, intervened by particularly diverse and lengthy MSA and LSA sequences. The "pre-Aurignacian" was estimated by McBurney to date to $\sim 80-60 \mathrm{ka}$ but is now thought to be significantly older, possibly extending into MIS 6 (Moyer 2003; Barker et al. 2007) (an ongoing dating program is addressing this). Although McBurney argued for relatively continuous occupation of the cave from the "pre-Aurignacian" to the present day, gaps are present in the sequence and the density of material is highly variable throughout the profile (Klein and Scott 1986), particularly in the "pre-Aurignacian" and later MSA layers. Since McBurney's excavations, several other researchers have analyzed different aspects of both the faunal (Klein and Scott 1986; MacDonald 1997; Wall-Scheffler 2007) and lithic (Close 1986; Chazan 1995; Hiscock 1996; Moyer 2003) collections. In 2007, the Cyrenaican Prehistory Project (later becoming the TRANS-NAP project) embarked on renewed investigations of the cave (Barker et al. 2007, 2008, 2009, 2010; Hunt et al. 2010, 2011), with the aim to re-excavate new trenches alongside McBurney's old section faces and conduct high resolution sampling for dating, paleoenvironmental and lithic analyses. Research at Haua Fteah is ongoing, involving multiple project members and analytical techniques.

This chapter reports new data collected during geoarchaeological surveys of an area of $\sim 150$ by $150 \mathrm{~km}$ that traverses four different ecological zones. From north to south, these are the littoral, upland, pre-desert and desert zones (Fig. 5.1). The littoral zone is a narrow coastal 
strip, dominated by Mediterranean vegetation and bordered by the steep northerly escarpments of the Gebel Akhdar. Haua Fteah lies within the littoral zone, $\sim 1 \mathrm{~km}$ south of the shoreline. Quaternary deposits are common here, where north-flowing wadis incise the Gebel, depositing alluvium at their terminus. Raised beach deposits also exist, some revealing surface and in situ lithic artifacts (McBurney and Hey 1955). The Gebel Akhdar, a 200 by $50 \mathrm{~km}$ (McBurney 1967: 324) upland zone, is an area of relatively high precipitation (approximately 200-550 mm annual rainfall [McBurney and Hey 1955; Elfadli 2009]) and ecological productivity within an otherwise semi-arid coastal strip and arid hinterland of North Africa. Reaching a maximum height of $\sim 879 \mathrm{~m}$ above mean sea level (amsl), the Gebel dramatically terminates in the north and west as two escarpments, yet gradually diminishes in elevation to the south and east. The uplands and escarpments are dissected by numerous wadi systems and their tributaries, forming steep-sided gorges in certain areas. Vegetation coverage is typical Mediterranean maquis scrub and some areas are heavily forested, receiving snow coverage in winter. As the Gebel gradually descends southwards, there is a sharp decline in vegetation, partly caused by climate (particularly a southwards decrease in precipitation) but also by overgrazing by livestock. This gradually undulating and relatively dry and devegetated landscape marks the beginning of the pre-desert, with a gradual southwards decrease in plant cover until reaching the desert proper. These zones are also characterized by river channels that have their headwaters in the uplands, run through the pre-desert and terminate in fans feeding paleolakes in the desert. Divisions between pre-desert and desert are somewhat arbitrary, and the boundaries between them would have fluctuated during MIS 6-2 as the rivers and lakes oscillated between being perennial and ephemeral.

PLACE FIGURE 5.1 ABOUT HERE; WIDTH = 2 COLUMNS 
The first geoarchaeological investigations were conducted in the southern Gebel Akhdar, pre-desert and desert during two field seasons in 2009 and 2010 (Barker et al. 2009, 2010; Jones et al. 2011) (authors: SJ, LF, ND, KW, HB). In the same years, a second team surveyed the coastal zone and Wadi Derna, building on previous work conducted by McBurney and Hey (1955) (authors: AA, CH). Additional sites were recorded in the area immediately surrounding Haua Fteah during surveys in 2007 and 2008; however, less archaeological information is available due to a different recording system. Surveys of the Gebel, pre-desert and desert employed a different methodology from those conducted along the coast and Wadi Derna. In the former, analysis of remote sensing imagery followed by targeted ground survey proved to be the most valuable starting point, given the large size of the study region and the unexplored nature of territories to the south of the littoral zone. Landsat TM and ETM+ false-color composite images were used to locate particular areas of interest (Barker et al. 2009, 2010), from the enclosed topographic depression at Al-Marj to headwaters, wadi channels, plateaus, stony desert plains, alluvial fans and paleolakes. An objective was to explore the archaeological record of a variety of landforms with the aim to discern relationships between a site's geomorphological context and the archaeology therein (Jones et al. 2011). While the vast majority of sites discovered in the Gebel, pre-desert and desert consisted of surface lithic scatters, artifacts at Al-Marj are exposed in the sections, spoil heaps and floor of an $\sim 8.5 \mathrm{~km}$-long and $\sim 3$ m-deep canal that was dug into the northern end of the basin in the late 1970s. An 29 m-deep core was drilled in this former enclosed lake basin, nestled within the western Gebel Akhdar, in order to collect samples for paleoenvironmental reconstruction (Barker et al. 2010). A principal objective of the coastal and Wadi Derna surveys was to locate sites with in situ Paleolithic artifacts and establish the relationship between paleoenvironmental and cultural change along the coast (Antoniadou 2012). At these sites, the lithostratigraphy and paleoenvironmental signatures of sedimentary sequences were 
established using gross sedimentary characteristics, thin-section analysis, palynology and mollusks, and samples were collected for radiocarbon, OSL and Uranium-series dating. With the exception of data recorded in 2007 and 2008, all sites were recorded using the same forms, enabling direct comparison of data. Artifact descriptions were included in these forms and small collections of surface lithics were often made. Where possible, material was assigned to an appropriate period of the Paleolithic. As the majority of sites consist of surface lithic scatters, dating the artifacts remains a considerable problem. As a means to partially resolve this, one of the ongoing objectives of the TRANS-NAP project is to use detailed technological comparisons of lithics from Haua Fteah and the landscape sites, together with an ongoing and extensive program of dating the cave's sediments, to narrow down the age of many of the region's surface lithic scatters. As part of this objective, it is important to account for potential technological variation caused by spatial as well as temporal differences in behavior (e.g., those caused by cave-based versus wider landscape-based activities).

\section{Archaeological Patterns across Biomes in Northern Cyrenaica}

Four seasons of archaeological surveys across the region from 2007 to 2010 resulted in the identification of 170 new archaeological sites. Tables 5.1 and 5.2 present data from all of these sites, as well as Haua Fteah, Hagfet ed Dabba (CPP1647) and Hajj Creiem (CPP1825a), which have been documented previously (McBurney and Hey 1955; McBurney 1967). Sites within each biome have been grouped into different geographic clusters (Fig. 5.2). The number of sites in each cluster is not a measure of occupation density but is a function of survey bias. Some areas have been surveyed more intensively than others; for example, the littoral and hinterland areas to the north and south of Haua Fteah respectively, the Baltat ar Ramlah (east) paleolake and the Al-Marj canal. The range of site elevations for each geographic cluster, derived from 30 m resolution ASTER DEM using a GIS, is provided to 
express the wide spectrum of site elevations within the Gebel Akhdar in particular. Geoarchaeological data is given for sites in each geographic cluster, including: (1) the type and frequency of different landforms on which sites are located; (2) the number of sites revealing MSA, LSA and both MSA and LSA technologies, as well as those that preserve lithics which cannot be assigned reliably to either the MSA or LSA; and (3) typical lithic technologies encountered in each geographic cluster (Fig. 5.3). The presence of certain lithic technologies as well as other traits has enabled some sites to be assigned to different phases within the MSA, suggesting considerable MSA variation across the region. Table 5.1 also gives the number of those archaeological sites where sources of chert were encountered. Depending on the year and location of the survey, this site attribute was not always sought or recorded, and the chert source figures are therefore an underestimate. Chert sources were always recorded during surveys of the desert, pre-desert and most of the Gebel. Figs. 5.4 and 5.5 illustrate the location of MSA and LSA sites encountered in each geographic cluster, including those sites with sources of chert.

PLACE FIGURE 5.2 ABOUT HERE; WIDTH = 2 COLUMNS

PLACE FIGURE 5.3 ABOUT HERE; WIDTH = 2 COLUMNS

PLACE TABLE 5.1 ABOUT HERE

PLACE TABLE 5.2 ABOUT HERE

\section{Littoral}


Two sets of deposits are present in the littoral zone, to at least $90 \mathrm{~m}$ amsl. These include marine, lagoonal and shoreline deposits, interbedded with highly lithified alluvial fan and colluvial sediments. The younger coastal sequences extend to at least MIS 7 and deposits of at least two and possibly as many as four sea level highstands are represented. These are interbedded with complex and laterally variable deposits including lagoonal clays, aeolian sands, alluvial fan gravels, paleosols, colluvial diamicts and screes. Also present are deposits of a major paleolake system in the Wadi Derna, which persisted from MIS 5 into the Late Glacial. The deposits at Hajj Creiem (McBurney \& Hey 1955) are part of this lacustrine depositional complex.

Archaeological materials are widely distributed throughout the coastal zone; 44 sites have been recorded, although few have yielded large collections. These are divided into six different zones based on geographic location (Table 5.1; Fig. 5.2), yet all are similar in terms of elevation and the types of landform present. All are found at elevations $<87 \mathrm{~m}$ amsl, where most sites are located below $49 \mathrm{~m}$ amsl. The majority of sites (75\%) are situated on coastal terraces (including raised beach deposits), where lithics are either on the surface or in situ. Of the coastal sites, 34\% are MSA, 14\% LSA and 9\% preserve both MSA and LSA technologies (the remaining $43 \%$ of sites preserve lithics that cannot be assigned to a particular period). Typical artifact types found in these open coastal sites include Levallois cores and flakes, as well as blades and bladelets (including backed varieties). Sites showing in situ MSA core reduction are associated with MIS 5 and possibly MIS 7 raised beaches. An Aterian presence is not evident in any of the coastal sites documented as part of this study; however, tanged artifacts are reported from Haua Fteah (McBurney 1967) and at Ras Aamer (McBurney and Hey 1955). Later LSA material with "Dabban" affinities is not widely distributed in the littoral zone; however, one site near Haua Fteah consists of a $\sim 28.0$ cal kBP fireplace (IntCal09 calibration curve) associated with a long blade industry in a skeletal paleosol 
interbedded in valley-fill deposits. Older, higher-level marine, lagoonal and riverine deposits are also present, which were laid down during one or more marine transgressions rising to $\sim 90 \mathrm{~m}$ amsl. A single U/Th date suggests that these deposits are more than $350 \mathrm{ka}$. Very rare cores and flakes are present within the basal conglomerate of the transgressive marine deposits, making these the oldest known artifacts in the region so far. Significantly, this is consistent with a pre-modern human presence in the region during the Middle Pleistocene.

\section{Gebel Akhdar}

The 85 sites recorded in the Gebel Akhdar fall into seven different zones, based on geographical location and topographic and landform differences. The majority $(n=37)$ of these are located in the Al-Marj Basin, an area that is archaeologically unique in terms of the types and densities of artifacts present. The 1970s, canal cutting through the basin has exposed MSA and possibly late Acheulean artifacts within alluvial and lacustrine sediments. Lithic types include numerous core forms (e.g., Levallois, discoidal, bifacial, multi-platform), tanged and stemmed artifacts, and numerous handaxes of various shapes and sizes. These artifacts are found within the canal's sections, predominantly in fluvial gravels and sands, and exhibit different states of patination and abrasion. Currently, it is not possible to establish a chronology for the different artifact types as the majority of artifacts recovered so far are either in reworked fluvial contexts or are surface finds. Al-Marj potentially preserves artifacts from the Late Acheulean, early MSA and Aterian; however, the presence of handaxes could equally be part of the region's MSA tradition. It is significant that the discovery of true Acheulean bifaces was extremely rare during the landscape surveys undertaken by McBurney (McBurney et al. 1948; McBurney and Hey 1955). An earlier surface collection of seven bifaces from Tocra (McBurney 1947) and a broken butt from a putative "amygdaloid" biface from Lete (Petrocchi 1940), both near Benghazi, are the nearest Acheulean material, albeit 
broken and heavily worn. Three handaxes, however, were described as possessing a smooth patina and sharp edges suggesting they had eroded out relatively recently (McBurney 1947: 78). Of these three pieces one is discoidal and another is also more likely to be a core (McBurney 1947: Fig. 15, No. 3). This material was considered to be an "evolved AcheulianMiddle Palaeolithic type” (McBurney 1947: 78). A small number of other bifacial pieces have been recorded but these are thought to be Neolithic (McBurney 1947; McBurney \& Hey 1955). Given this paucity of evidence, $H$. sapiens may have been the first hominin species to inhabit Cyrenaica, using an industry that was either late Acheulean or part of the MSA. The presence of a biface in the "Levalloiso-Mousterian" layers of Haua Fteah might suggest the latter. The apparent absence of earlier Middle Pleistocene and Early Pleistocene technologies is surprising given that the Gebel Akhdar was relatively resource-rich for hominins, when compared to other regions of Libya, and that earlier technologies (handaxes and pebble tools) have been found at sites in other areas along the northern fringe of North Africa (e.g., Ternifine and Ain Hanech in Algeria) (McLaren and Reynolds 2009: 778). It remains to be confirmed if this reflects a true absence of evidence or if there is a taphonomic explanation, such as a lack of earlier Pleistocene deposits either preserved or exposed in the landscape.

Excluding the Al-Marj sites, of the remaining Gebel Akhdar lithic sites, $8 \%$ are MSA, $38 \%$ are LSA, $2 \%$ preserve both MSA and LSA artifacts and 52\% are of unknown period. The elevation ranges for the Gebel sites vary widely. Three of the geographic clusters are very close to the coast (ranging from 90-289 m amsl), where Al-Marj, Wadi Derna and the Haua Fteah hinterland sites are $<15 \mathrm{~km},<8 \mathrm{~km}$ and $<2 \mathrm{~km}$ from the coast respectively. These areas have revealed notably more MSA than LSA sites. In Wadi Derna, 40 m-thick sequences suggest that fluvial deposition from late MIS 6 was followed by lacustrine deposition behind a series of tufa dams from MIS 5-2. The MSA site at Hajj Creiem is interbedded within these paleolake deposits. LSA material of "Dabban" affinities is less widely distributed, yet a small 
fireplace and two long blades in cool-climate Wadi Derna paleolake deposits are associated with a finite radiocarbon age of $\sim 52.0{ }^{14} \mathrm{C} \mathrm{kBP}$ (this date is beyond calibration but may equate to a period of $\sim 58-55 \mathrm{ka}$ ). Moving further inland (southwards) the number of MSA sites in the Gebel reduces dramatically and only LSA sites are found at higher elevations (i.e., in the Upper Gebel and in the southern sites of the North Gebel cluster). LSA sites in these regions are typically represented by low-density surface scatters of flakes, blades and bladelets, including backed forms, geometric microliths and bladelet cores. Artifacts are mostly either lightly patinated or unpatinated, with and without abraded edges, and commonly manufactured on a high quality blue-grey chert, sources of which have yet to be discovered. A lack of visible sources, the low density of the lithic scatters and an absence of in situ flaking products all suggest that these were the product of mobile hunter-gatherer populations that carried out chert exploitation and the early stages of lithic reduction elsewhere. These LSA sites are likely to be terminal Pleistocene or early Holocene in date (Barker et al. 2009). The scatters of backed blades and blade and microblade cores, encountered during surveys along the Wadi el Qlaa in the North Gebel cluster, have been likened to the Dabban and Oranian layers at Haua Fteah (Barker et al. 2010).

\section{Pre-desert}

The 44 sites in the pre-desert region have been divided into six geographic clusters; four are located in the lower reaches of wadi systems that originate in the Gebel and drain southwards across the pre-desert. Two clusters are paleolake regions, both at the terminus of the Wadi arRamlah. The majority of sites in the pre-desert are MSA (53\%), followed by sites with both MSA and LSA artifacts (18\%) and just LSA (16\%). The geoarchaeology of the pre-desert region has been described in detail (Barker et al. 2009), with important associations noted between particular landforms in the region and the age and characteristics of surface lithic 
scatters on those landforms (Jones et al. 2011). The lithics are typically found on deflated surfaces. While many assemblages are palimpsests, at a number of sites discrete clusters of artifacts are visible that appear to be of comparable antiquity. Early MSA artifacts are present at seven sites in the pre-desert, mainly represented by weathered (patinated and abraded) bifacial and discoidal cores coated in desert varnish. More generalized MSA sites are present, marked in particular by the presence of typical Levallois cores. Two fragments of possible tanged points may suggest an Aterian presence, although the evidence for this is weak. Late MSA technologies are tentatively suggested by the presence of lithic scatters at some sites where Levallois and blade reduction strategies are both present, where the artifacts appear to be more or less contemporary (suggested by similar states of weathering) and are younger than earlier MSA lithics in the region (indicated by an absence of desert varnish and heavy weathering). The few LSA sites in the region are represented by scatters of backed blades and bladelets, all of which are in a relatively fresh condition.

Chert sources have been observed at $23 \%(n=10)$ of the pre-desert sites. The Wadi Samalus area revealed nodular chert sources within limestone bedrock at six sites and evidence of primary flaking activity at three of these. The Baltat ar Ramlah (east) paleolake has been surveyed relatively intensively, revealing one particularly important site, CPP 8009, where there is a high density scatter of MSA lithics (possibly later MSA), located on an area of raised ground (a "paleolake island", 400 by $250 \mathrm{~m}$ ) within the paleolake. Here, chert has been prized from outcrops within the limestone bedrock. In the immediate vicinity, there is evidence of high-density lithic scatters and large rotated cores attesting to the early stages of core reduction. Refined Levallois cores, blades, retouched flakes and other artifact types are present throughout the island and there is also evidence of artifact recycling, suggesting that the area was repeatedly visited by hominin groups. 


\section{Desert}

The Baltat lawlah al Halq paleolakes were identified using remote sensing imagery and subjected to a small-scale geoarchaeological survey. Eight sites were recorded in eastern and western paleolakes in the Baltat lawlah at Halq system: MSA $(n=5)$, MSA and LSA $(n=1)$ and LSA $(n=2)$. A source of chert was recorded at one of these sites. MSA artifacts include heavily weathered discoidal cores and flakes with desert varnish as well as relatively fresh Levallois cores. The differences in weathering patterns suggest that these artifacts may belong to different phases of the MSA. The LSA is represented by blade and microblade technologies; however, the presence of a Neolithic bifacial point means that these may be early Holocene rather than terminal Pleistocene in age.

PLACE FIGURE 5.4 ABOUT HERE; WIDTH = 2 COLUMNS

\section{PLACE FIGURE 5.5 ABOUT HERE; WIDTH = 2 COLUMNS}

Three main patterns are evident from the results of geoarchaeological surveys across all four biomes. First, MSA sites are mainly concentrated around the paleolakes of the desert and pre-desert, along the southern flanks of the Gebel where chert sources are available, and along coastal Cyrenaica and a relatively short distance inland into the Gebel Akhdar. In contrast, there is a dramatic reduction in the number of MSA sites at higher elevations in the Gebel; instead, late Pleistocene and possibly early Holocene LSA sites prevail. After excluding the Al-Marj sites, located in the Gebel but within a topographic depression and only $\sim 15 \mathrm{~km}$ from the coast, as well as the desert sites as they are too few in number for statistical testing, there exists a statistically significant relationship between biome and the frequency of MSA and LSA sites present in those biomes $\left(\chi^{2}(2)=21.573, \mathrm{p}<0.001\right)$. 
According to this chi-square test, both the littoral and pre-desert zones have significantly more MSA and fewer LSA sites than expected, whereas the Gebel Akhdar has more LSA sites and fewer MSA sites than expected. Second, confirming this observation but including all 181 sites located in the four biomes and 21 geographic clusters, a comparison of site elevations (using ASTER $30 \mathrm{~m}$ resolution elevation data) for MSA sites, LSA sites and sites where both MSA and LSA lithics are present reveals that the only statistically significant relationship exists between LSA sites and MSA sites. Here, significantly more LSA sites are located at higher elevations than MSA sites (Kruskal-Wallis test, $\mathrm{p}=0.017$ ). Pairwise comparisons reveal no statistically significant differences between the elevations at which LSA versus MSA and LSA sites are found, or between those at which MSA versus MSA and LSA sites are located (Fig. 5.6). Third, there is substantial typo-technological variation within the MSA across the study region. There are at least three different types of MSA assemblages that probably belong to earlier phases of the MSA: (1) the "pre-Aurignacian", known from Haua Fteah; (2) the handaxe and Levallois core technologies at Al-Marj, although it remains to be determined if these were contemporary; and (3) the heavily weathered discoidal and bifacial chert cores with desert varnish from the pre-desert and desert. In addition, other phases of the MSA are also suggested: (1) a general MSA with prepared core technologies, including classic Levallois cores and discoidal cores exhibiting centripetal preparation; (2) the Aterian on the coast and possibly at Al-Marj and Baltat ar Ramlah, although an Aterian presence in the region as a whole is relatively weak compared to other regions of North Africa; and (3) a later MSA phase represented by a combination of Levallois and blade reduction strategies.

PLACE FIGURE 5.6 ABOUT HERE; WIDTH = 2 COLUMNS 


\section{Discussion}

Surveys of the TRANS-NAP study region have revealed the presence of Paleolithic artifacts in surface and in situ contexts across all four ecological zones and associated with varied landforms. Although a clear chronology for these sites is currently lacking, dates have already been obtained for some coastal sites with in situ archaeology that extend back into the Middle Pleistocene. Without direct dates for the surface archaeology, we have to rely on information garnered from the techno-typological criteria of the lithic scatters. Using this approach, 80 of the sites across the region preserve lithics with MSA affinities, 33 with LSA, 14 with both MSA and LSA, and 54 of unknown affiliation. Although MSA and LSA sites are distributed throughout the surveyed area, two main patterns in the archaeological record are apparent: (1) a difference in MSA and LSA site location according to elevation; and (2) notable technological diversity within the MSA in particular. Explanations are provided for why this dichotomy between the distribution of MSA and LSA sites may exist. For example, why were paleolakes a focus of MSA occupation and why is there a lack of MSA sites at higher elevations in the Gebel Akhdar? Causes of the diversity seen in the MSA are proposed, emphasizing possible underlying microevolutionary processes. The surveyed area is considered in terms of the resources available to human populations and how changing resource distribution may have governed hominin behavioral adaptations as well as population dynamics in the region.

\section{MSA and LSA Patterns of Occupation in Northern Cyrenaica}

Water supply would have been a driving force behind occupation patterns and population densities across the region, where water availability dictated the type and abundance of plant and animal resources. In the coastal zone and Gebel Akhdar, the presence of numerous springs and relatively high precipitation rates offered sufficient water for hunter-gatherer 
groups, even during glacial periods when large areas elsewhere in North Africa were experiencing hyper-arid conditions. These regions were comparatively rich in plant and animal foods, from marine resources and terrestrial land snails to game of varying sizes. In fact, archaeological remains from Haua Fteah indicate that adaptations such as marine resource exploitation were present from as early as the "pre-Aurignacian" (Klein \& Scott 1986). Today, vegetation cover in the pre-desert and desert is substantially less, albeit not entirely absent in the former. Here, arid-adapted animal species would have represented suitable prey, perhaps constituting a more reliable source of energy than plant foods. Contrasting with water supplies to the coast and Gebel, those to the pre-desert and desert zones were unpredictable but not absent. Since 1985, Landsat TM Quicklooks imagery reveals that the Baltat ar Ramlah paleolake has contained water approximately every five years, providing a source of water for livestock for more than a year in man-made trenches dug into the paleolake (Jones et al. 2011). Modern wells in the vicinity also attest to water sources in the area. Moving further south into the desert paleolakes, water becomes increasingly unavailable. Drawing on evidence from other studies (e.g., Osborne et al. 2008; Drake et al. 2008, 2011), the paleolakes and wadis in the pre-desert and desert would have been relatively well-watered environments during interglacial periods, exhibiting greater plant cover and attracting animals and human groups. Increased water supply during humid episodes in MIS 5 in particular is argued to have been one of the main factors determining MSA occupation in these biomes, with the most viable habitats and reasonably long-term and high-density occupation being most likely during MIS 5e. In contrast, arid conditions of the later Pleistocene explain a relative lack of terminal Pleistocene LSA sites in the area. This has been noted in other arid areas of North Africa from MIS 4-2 where populations existed at very low densities (Ambrose 1998) (e.g., in the Nile Valley [Van Peer and Vermeersch 2007; Barham and Mitchell 2008: 266]) or may have abandoned areas such as the Libyan Sahara 
after 60 ka until the Holocene (Cremaschi et al. 1998). Microlithic surface sites do exist in the pre-desert and desert, yet some or all of these may be early Holocene in age.

In addition to providing water and a diverse array of food resources during humid periods, the pre-desert and desert paleolakes would have attracted MSA hominins for two further reasons: (1) their location along potential dispersal routes that followed waterways located to the south, east and west, active during humid interglacials; and (2) the sources of chert on the "paleo-islands" and southern escarpments of the Gebel, as is suggested by the presence of in situ flaking scatters, evidence of chert extraction from limestone boulders and large cores in the early stages of reduction. In fact, the location of chert sources across all four biomes suggests that proximity to raw materials was a driving force behind MSA site location and may explain the lack of MSA sites at higher elevations in the Gebel. Chert sources are documented in the pre-desert and desert paleolakes, are readily available both along the coast and at lower elevations in the northernmost parts of the Gebel, and are present in abundance and are of high quality in the Al-Marj Basin. These are all places where MSA sites are located, whereas chert sources are far more elusive in the Gebel at higher elevations. At these elevations, LSA artifacts were commonly made from a high quality blue-grey chert, the source(s) of which remain unknown. As all lithic scatters in these areas are low density, the LSA populations whose traces exist in the Upper Gebel were possibly not as tethered to raw material sources as MSA groups; instead, these LSA sites are the remnants of small mobile hunter-gatherer groups with portable tool-kits, exploiting the Gebel for its plant and animal resources. The LSA sites in the Gebel and coastal biomes could represent the terminal Pleistocene backed bladelet producing populations that spread across coastal North Africa after $20 \mathrm{ka}$, from the Near East to the Maghreb (Close 2002; Barton et al. 2007) but were either absent or existing at very low population densities in the more arid regions of North Africa. Arguably, the relatively high number of LSA sites along the coast and in the Gebel 
was a result of population compaction into these areas during MIS 2, following a contraction of viable habitats. As seen in Haua Fteah, evidence of LSA technologies continues into the early Holocene with the Capsian (McBurney 1967; Barker et al. 2009) and some of these LSA sites could also date to this period.

\section{MSA Diversity in Northern Cyrenaica}

The MSA of North Africa exhibits considerable technological diversity. This was probably a result of both diachronic change and contemporary regional variation in the cultural record. In order to qualify and quantify this technological diversity, further chronological resolution of the archaeological record is required, and different regional research approaches, terminologies and typologies need to be taken into account. Currently, various early MSA records are documented across North Africa, including those from the: (1) Western Desert in Egypt, at Bir Tarfawi and Bir Sahara East from 230 ka (McBrearty and Brooks 2000) and at Kharga Oasis $220 \pm 20 \mathrm{ka}$ (Churcher et al. 1999); (2) Nile Valley from early MIS 5 (early Nubian complex) (van Peer 1998); (3) Jebel Gharbi in northwest Libya during MIS 5 ("generalized" early MSA, lacking tanged artifacts) (Barich et al. 2006); (4) the "preAurignacian" at Haua Fteah, dating to MIS 5 and possibly MIS 6 (Moyer 2003; Barker et al. 2007); and (5) 171 ka levels (lacking tanged artifacts) in Ifri n'Ammar cave in Morocco (Richter et al. 2010). The presence of tanged points is regarded as marking the North African Aterian culture, one of the many African MSA variants (e.g., Clark 1992), and assumed by some to succeed the early MSA. Garcea (2010a), for example, argues that the Aterian in northwest Libya follows the early MSA after a hiatus and population discontinuity. Others argue that the Aterian may not represent a chronologically distinct cultural complex, where "Middle Paleolithic" layers at Ifri n'Ammar ( 171 ka and $\sim 130 \mathrm{ka})$ alternate with Aterian layers ( $\sim 145 \mathrm{ka}$ and $\sim 83 \mathrm{ka})$, based on a respective absence and presence of tanged points 
(Richter et al. 2010). This appears to be the case at other sites in North Africa, including Haua Fteah, where the putative Aterian layers are succeeded by "Mousterian" layers (McBurney 1967; Wendorf and Schild 1992; Richter et al. 2010). An absence of tanged points is argued to not necessarily denote the absence of the Aterian (Garcea 2012a), as other lithic technologies are also included in the Aterian, such as bifacial foliates, small Levallois and discoidal cores, an increase in flake laminarity (Stringer and Barton 2008) and flakes with bulbar basal thinning and bifacial retouch (Garcea 2010a). Yet, all of these can be part of nonAterian MSA assemblages in North Africa, elsewhere in Africa and outside Africa. The definition of the Aterian remains problematic (e.g., Kleindienst 2001) and circular arguments regarding what is and what is not "Aterian" are commonplace. In contrast, the Nile Valley MSA record appears to be more diverse than that further to the west; however, to some extent this could be a result of different regional research strategies and ways of describing the lithic evidence. Technological differences between Nile Valley assemblages reveal an early Nubian complex (early MIS 5), later Nubian complex (later MIS 5), Lower Nile Valley complex and Khormusan (MIS 4 and early MIS 3), Taramsan (MIS 3) (Van Peer 1998; Vermeersch 2010), and absence of the Aterian. Leaving definitions of the latter aside, this brief review of the North African evidence reveals a complex MSA record (see Van Peer this volume), perhaps unsurprising given the paleoclimatic and demographic shifts that influenced the region from MIS 6 onwards.

Geoarchaeological surveys of the TRANS-NAP study region have revealed a comparable level of diversity within the MSA of northern Cyrenaica. In Haua Fteah, this diversity can be arranged chronologically, whereas only a relative chronology can be applied tentatively to the surface archaeology. Temporal as well as spatial factors may explain the variety of MSA technologies evident across the landscape. For example, three different forms of early MSA are discernible that may or may not overlap chronologically. These include the 
"pre-Aurignacian" at Haua Fteah, heavily weathered discoidal cores with desert varnish at pre-desert and desert surface sites, and the Levallois cores and handaxes found throughout the Al-Marj canal; however, the stratigraphic relationship between the latter technologies at AlMarj remains unresolved. Other forms of MSA are evident, including a more general MSA, characterized by reduction techniques such as Levallois, centripetal and radial, and a possible late MSA that features both Levallois flake and blade cores. If defined on the basis of the presence of tanged or foliate points, an Aterian signature in the region is weak, particularly in the pre-desert and desert biomes. This is in conflict with evidence from elsewhere in North Africa where Aterian technologies are argued to represent an adaptive response by huntergatherers inhabiting arid environments with ephemeral water sources (Garcea 2012b; cf. Drake and Breeze this volume). The lack of Aterian lithic types in the pre-desert and desert may be a case of absence of evidence rather than evidence of absence, or it may suggest that technological adaptations were different in this region of North Africa when compared to similar environments elsewhere. More controversially, this pattern may reflect a true demographic divide between Cyrenaica and other regions where Aterian technologies are clearly present.

To explain the possible causes behind diversity in the MSA of northern Cyrenaica without a clear chronology for the surface assemblages does present a challenge. There are a number of factors, not necessarily mutually exclusive, which may underlie this diversity, for example: (1) late Middle and Late Pleistocene paleoenvironmental change; (2) fluctuating population densities and structure within the region; (3) migration of populations into and out of the region; and (4) behavioral adaptation to different habitats and resources therein (e.g., food, water and raw materials). Reconstruction of past paleoenvironments in the region is part of the TRANS-NAP project's ongoing research, particularly with respect to the Haua Fteah sediments, Al-Marj core, raised beach deposits and Wadi Derna sections. McBurney (1967) 
and others identified alternate cold and warm phases in Haua Fteah, by analyzing gross sedimentology (Sampson 1967), faunal profiles (Higgs 1967; Klein and Scott 1986) and conducting pioneering oxygen isotope studies of shell (Emilani and McBurney 1967). While ages for climatic phases older than $\sim 46$ ka were not based on chronometric dates, the age and characteristics of these phases are currently being revised and refined using various dating techniques. New evidence from Haua Fteah reveals a major phase of cooling in the MSA levels as indicated by layers of limestone roof-spall that correlate broadly with MIS 4 (Barker et al. 2008, 2009; Inglis 2012) and a drop in occupation density. A further decline in MSA occupation occurred with the deposition of sediments that mark warmer but fluctuating environments, corresponding to the global climatic oscillations of MIS 3.

Unlike in the littoral zone, explorations of the pre-desert and desert zones have produced few sections suitable for paleoenvironmental studies. Here, a key issue concerns the relationship between paleohydrological fluctuations in these biomes and cultural diversity. For example, there is clear evidence of humid and wet conditions across the Sahara in MIS 5e (Osborne et al. 2008; Drake et al. 2011). During MIS 5e and Middle Pleistocene humid interglacials, large lakes (e.g., Lake Megafazzan) and river systems (e.g., Kufra) are argued to have covered $\sim 10 \%$ of Libya. Although there were several humid episodes after $\sim 120 \mathrm{ka}$, these resulted in smaller and more fragmented lake systems, marking a trend towards an overall reduction in water availability during the Late Pleistocene (Drake et al. 2008). Such humid episodes are documented in the Fazzan Basin at 100 ka, 74 ka, 47 ka, 30 ka and 14-13 ka (Mattingly et al. 2007), marking the activation of lakes (White et al. 2006). At Bir Tarfawi in the Eastern Sahara, different phases of the MSA are associated with different phases of lake activity in the late Middle and Late Pleistocene (Wendorf et al. 1987). Substantial lakes are absent from this region from MIS 4-2 when humid periods would have been short-lived and low intensity, yet it remains unclear how habitable the area would have been during such 
periods (Smith 2010). Although the eastern Sahara is $~ 1100 \mathrm{~km}$ south of northern Cyrenaica, similar humid cycles may have occurred in the latter from MIS 6 onwards that were probably greater in intensity given the relatively high precipitation rates in the Gebel Akhdar. Of particular relevance to northern Cyrenaica is the identification of cold and dry phases in the alluvial fan sequences derived from the Wadi Zuiana ( 90 km west of Haua Fteah) at various times from MIS 6-2 (Rowan et al. 2000; Macklin et al. 2002). Phases of alluviation occurred during arid periods, with the transition from forested steppe-to-steppe vegetation and subsequent land surface destabilization. Two alluviation episodes occurred during MIS 6 at $\sim 183-179 \mathrm{ka}$ and $\sim 157-138 \mathrm{ka}$, correlating with periods of substantial global cooling. Other periods of alluviation occurred $\sim 111-109 \mathrm{ka}$ (MIS 5d), $>88 \mathrm{ka}$ (MIS 5b/5a boundary), 69 ka (MIS 4), 42 ka (MIS 3) and three times during MIS 2. In contrast, periods of incision took place during humid peaks in MIS 5e and the early Holocene (Macklin et al. 2002). These alternating arid and humid phases from MIS 6-2 would have resulted in fluctuating environmental conditions and been one of the factors underlying shifts in human behavior and the diversity of lithic technologies from the MSA onwards.

Various microevolutionary processes, driven by paleoenvironmental changes from MIS 6-2, influenced past population dynamics in the region. During humid phases, an increase in cultural change and diversity in the region is predicted, where both demographic expansions within the region and the arrival of new populations resulted in new social structures, cultural exchange and transmission, and consequently, technological change and an increase in cultural diversity. In the pre-desert and desert zones, pulses of occupation during humid phases are hypothesized, with long periods of no occupation. This ebb and flow of new populations into the region at different points in the past could explain some of the region's MSA technological diversity. Habitats of the northern Gebel Akhdar and littoral zone contrast starkly with those of the pre-desert and desert, essentially representing an island of more 
Mediterranean-like vegetation and fertile landscape than the arid landscapes to the south, east and west. This area likely acted as a refugium during cold and dry phases across North Africa. Although population extinctions were unlikely in both the Gebel Akhdar and coastal biomes as a result of climatic downturns, smaller scale group extinctions were possible. During such periods, populations would have compacted into smaller areas, resulting in an increase in population density and possibly stimulating technological change through both increased competition and behavioral adaptation to altered population structure and habitats. Specifically long-term isolation of populations in the region could have taken place during extended climatic perturbations, potentially causing both a loss of cultural diversity through cultural drift (e.g., Henrich 2004) and technological differences between northern Cyrenaica and surrounding regions (e.g., the Nile Valley or Maghreb). Fluctuating population density is supported by evidence from Haua Fteah. This shows notable shifts in occupation intensity from the "pre-Aurignacian" to Dabban, with hiatuses documented in the "pre-Aurignacian" levels. Occupation densities are particularly low in the late MSA and early LSA layers, correlating broadly with the marked environmental fluctuations of MIS 3 (Inglis 2012). A human presence is, however, still documented in the cave during glacial periods in both the MSA and LSA (Higgs 1967; Klein and Scott 1986; Inglis 2012). In fact, the Late Dabban layers record an explosion in artifact numbers when compared to the Early Dabban, a jump that occurred as the area cooled (but did not necessarily become hyper-arid) towards MIS 2 . This potentially indicates a contraction of populations into certain locations that remained habitable, due to adequate local rainfall as well as the possible presence of springs (Inglis 2012). Littoral zone sites with bladelet-based LSA industries, presumably dating to during and after the LGM, are widely distributed in contexts that, if in situ, suggest both climatic amelioration (e.g., paleosols) and climatic severity (e.g., fluvial and colluvial deposits). 
Continuity of activity at relatively high densities from the Dabban through the LGM to the later LSA "Oranian" and "Capsian" is supported by the new excavations in Haua Fteah.

This technological diversity could be a result of environmental changes that caused demographic changes, for example, as a consequence of new populations that expanded into the region during pluvial periods, along the coast from areas to the west and east, or across the Sahara. Yet, a degree of this diversity would have been a consequence of behavioral adaptation by pre-existing populations to altered habitats as well as social structures and practices. This may explain some of the spatial as well as temporal cultural differences within the study area. For example, shifts in hunter-gatherer subsistence strategies, caused by changes in resource type and availability, are argued to have varied in each biome because of differences in resource base. In short, hunting and gathering practices employed along the coast (e.g., for the exploitation of marine resources) would have been different from those required in the pre-desert and desert (e.g., to successfully hunt arid-adapted mammals), and these differences would have had technological manifestations. In addition, a degree of technological diversity can be explained by a site's proximity to stone materials. For example, many of the pre-desert and desert sites are close to raw material sources, yet the lower quality chert evident thus far in these biomes, when compared to that in coastal areas or at Al-Marj, may explain some regional behavioral and technological differences. In sum, the different factors that may be contributing to the patterns seen in the archaeological record are numerous and complex. It is very difficult to discern the extent to which the archaeological record marks indigenous cultural developments or signifies new populations in the region, or more plausibly, to what extent both processes were in operation. This is a problem further confounded by the absence of a decent sample of human remains from northern Cyrenaica and surrounding regions. At this stage, therefore, it is important to look beyond the study area 
and examine the geographic links that may have existed with other regions and how these might have influenced past population dynamics.

\section{Demographic Connections from MIS 6-2}

Considering the impact of population isolations and migrations on the Paleolithic record of the region raises questions about when and where connections existed between northern Cyrenaica and regions beyond. For example, was northern Cyrenaica at a "cross-roads" between the Maghreb, Sahara, Nile Valley and Levant, and if so, how did this manifest itself

in the archaeological record? Unfortunately, paleoclimatic and paleoenvironmental evidence is sparse and it is not possible to draw firm conclusions (Drake et al. 2013; Drake and Breeze this volume). The most likely timing of dispersals across the Sahara was during MIS 5, when the desert contracted and was replaced by grasslands and extensive lake and river systems (Osborne et al. 2008; Drake et al. 2011). Fossil river channels have been identified to the south of the TRANS-NAP study region, including the Kufra river system and the Serir-Tibesti and Sahabi rivers (Drake et al. 2008, 2011), as well as an $~ 800 \mathrm{~km}$-long uninterrupted drainage network running from the Tibesti Mountains to the Sirte Basin (Osborne et al. 2008). While these "corridors" represented plausible hominin migration routes, the archaeological signatures of these exact routes have yet to be discovered and it is unknown how frequently they were active in the past. Discoveries of artifacts from the Oldowan to Neolithic in "megalake" basins, the catchments of which form a corridor across the Sahara, do show that the desert was regularly, albeit periodically, occupied by people during climatic optima (Drake et al. 2008; 2011).

A trans-Saharan migration route to northern Cyrenaica that was active during the last humid phases is suggested by the presence of a diverse array of Sub-Saharan savannah fauna in the Late Pleistocene and Holocene deposits of Haua Fteah (Klein and Scott 1986). Other 
migration routes may have also been active during periods from MIS 6-2. For example, Drake and Breeze (this volume) show that the northern Sahara and the Levant show brief periods of humidity between $129 \mathrm{ka}$ and $92 \mathrm{ka}$ and at approximately $76 \mathrm{ka}, 44 \mathrm{ka}, 37 \mathrm{ka}$ and $29 \mathrm{ka}$. Consequently, population movements between Cyrenaica and these regions possibly occurred at these times. Low sea levels during glacial humid periods (e.g., $44 \mathrm{ka}, 37 \mathrm{ka}$ and $29 \mathrm{ka}$ ) would have exposed a larger, littoral plain along the north coast of North Africa; however, at the Gebel Akhdar a coastal plain would have been relatively limited given its steep offshore topography (Lambeck and Purcell 2005). If populations, avoiding hyper-aridity in the center of North Africa, were utilizing sites along this lower coastline, potentially as far as the Levant, then much of the evidence for occupation during such periods would now be submerged, hampering assessment of such linkages (Bailey and Fleming 2008; Garcea 2010b). It is possible that early LSA industries such as the Dabban were the result of such connections, with technological diffusion, not necessarily population diffusion (e.g., McBurney 1967), occurring within a broad southern Mediterranean littoral zone (Garcea 2010c). McBurney and Hey (1955: 7-8) favored a route along the Mediterranean littoral but also suggested an additional route that ran from northwest Libya to the Augila (Awjilah) oasis, along the northern extent of the Sand Sea and connecting with Siwa Oasis in Egypt. No paleoclimate research has been conducted in these regions to verify this route though there is evidence for humidity in the eastern Sahara between $129 \mathrm{ka}$ and $92 \mathrm{ka}$ and at about $76 \mathrm{ka}$ (Drake and Breeze this volume); therefore, at least the eastern part of this route would have been viable during these periods.

Several previous studies have looked at the paleohydrology of the Sahara, particularly from MIS 5e to the Holocene (Osborne et al. 2008, Drake et al. 2008, 2011; Smith 2010), yet northern Cyrenaica has been excluded from these models. Establishing the paleohydrological links between northern Cyrenaica and regions further to the south is crucial for identifying the 
potential routes that hominins may have taken into and out of our region, and when these routes were active. Fig. 5.7 provides an evaluation of Saharan paleohydrology, developed by Drake et al. (2011) who demonstrate how such links can be made. This shows the simplified Holocene paleohydrology of North Africa, illustrating a dense river network in most areas as well as numerous large paleolakes. Dating of the paleolake sediments in these basins shows that many of them were active during MIS 5 (Drake et al. 2011) and probably during previous humid periods. The Sahabi, Serir Tibesti and Kufra rivers link with fluvio-lacustrine systems in the southern Sahara, and form corridors across the desert that could have allowed hominin dispersals to the region just south of Cyrenaica. The Kufra River terminates in a giant alluvial fan $>500 \mathrm{~km}$ from Cyrenaica, while the Serir Tibesti and Sahabi rivers feed a giant paleolake. This paleolake, Sabkhat al Qenien, is only $65 \mathrm{~km}$ from the nearest hydrological system draining the Gebel Akhdar and therefore offers a more attractive route than the Kufra. Using methods outlined in Drake et al. (2011), Fig. 5.8 provides a map of the paleohydrology of the Cyrenaica/Gulf of Sirte region. This shows the existence of a number of routes into and out of the study region via the Sabkhat al Qenien. Hominin groups could have crossed the $65 \mathrm{~km}$ between the Sabkhat and the nearest Cyrenaican fluvio-lacustrine system. They could have followed the river that feeds into the Sabkhat from the east and drains towards the eastern coastal margin of Cyrenaica. Alternatively, they could have traversed the field of numerous small paleolakes found on the platform between Sabkhat and Cyrenaica. Together, this shows the existence of several viable routes that hominins may have followed between the Sahara and northern Cyrenaica during climatic optima. Some of the surface archaeology reported here, such as that from the pre-desert and desert paleolakes and wadis, may represent the first recorded signatures of people using such routes into and out of the study area. 


\section{PLACE FIGURE 5.8 ABOUT HERE; WIDTH = 2 COLUMNS}

\section{Concluding Remarks}

The distribution across the surveyed area of sites preserving typical MSA and LSA technologies reveals different patterns of occupation from MIS 6-2; for example, a lack of MSA sites at higher elevations and relatively few LSA sites in the pre-desert and desert. This pattern most plausibly reflects different adaptive responses to environmental change, shifting modes of resource exploitation (food, water and raw materials), dissimilar patterns of mobility and, arguably, differences in demographic structure and social behaviors. Despite this dichotomy between the MSA and LSA, the former itself was highly variable, both regionally and chronologically. This is unsurprising given that the MSA of the region lasted from at least MIS 6 until the middle of MIS 3, a period of significance in terms of climate change as well as modern human anatomical and behavioral evolution and dispersals. Population densities in the region fluctuated from MIS 6-2, evident from the cultural sequence at Haua Fteah and littoral sites with stratified archaeology. This is also apparent from the type and distribution of sites in the pre-desert and desert, areas that were not continuously occupied. Here, MSA and LSA sites are the result of an ebb and flow of populations that contracted and expanded across the landscape at various points in the past and probably in various directions. In contrast, areas of refugia likely existed in parts of the Gebel Akhdar and littoral zone, providing adequate resources of food, water and raw materials during climatic downturns. Several characteristics of the region's Paleolithic record are somewhat idiosyncratic when compared to the rest of North Africa (e.g., the "pre-Aurignacian", possible lack of Aterian, and Dabban). It is possible that the Gebel Akhdar's unique fertile geography in an otherwise arid area of North Africa provided extraordinary conditions for technological, behavioral and 
demographic change. Yet, to what extent these are truly idiosyncratic requires both precise chronologies for archaeological data and inter-regional lithic comparisons with assemblages from elsewhere in North Africa and the Levant. Only then will it be possible to refine our interpretations of the archaeological record, to test some of the aforementioned interpretations, and to reconstruct more precisely the complex processes behind hominin behavioral and demographic shifts in the region from MIS 6-2. 


\section{Acknowledgments}

Data presented in this paper were collected during four field seasons from 2007 to 2010 and involved numerous team members to whom we are most grateful. We thank the Department of Antiquities of Libya for permission to undertake this work and the European Research Council and the Society for Libyan Studies for financial support. We are indebted to our colleagues in Libya for their support, including Giuma Anag, Salah Aghab, Ahmed Buzaian, Ahmed Saber, Mohammed Twati and the late Abdulgader Mzeine. We thank the three reviewers for their important and helpful comments. 


\section{References}

Ambrose, S.H. (1998). Chronology of the Later Stone Age and food production in East Africa. Journal of Archaeological Science, 25, 377-392.

Antoniadou, A. (2012). The geoarchaeology of Cyrenaica, Libya. Ph.D. Dissertation, Queens University Belfast.

Bailey, G.N., \& Fleming, N.C. (2008). Archaeology of the continental shelf: Marine resources, submerged landscapes and underwater archaeology. Quaternary Science Reviews, 27(23-24), 2153-2165.

Balter, M. (2011). Was North Africa the launch pad for modern human migrations? Science, $331,20-23$.

Barham, L., \& Mitchell, P. (2008). The first Africans: African archaeology from the earliest toolmakers to most recent foragers. Cambridge: Cambridge University Press.

Barich, B.E., Garcea, E.A.A., \& Giraudi, C. (2006). Between the Mediterranean and the Sahara: Geoarchaeological reconnaissance in the Jebel Gharbi, Libya. Antiquity, 80, $567-582$.

Barker, G., Hunt, C., \& Reynolds, T. (2007). The Haua Fteah, Cyrenaica (northeast Libya): Renewed investigations of the cave and its landscape, 2007. Libyan Studies, 38, 93114.

Barker, G., Basell, L., Brooks, I., Burn, L., Cartwright, C., Cole, F., et al. (2008). The Cyrenaican Prehistory Project 2008: The second season of investigations of the Haua Fteah cave and its landscape, and further results from the initial (2007) fieldwork. Libyan Studies, 39, 175-221.

Barker, G., Antoniadou, A., Barton, H., Brooks, I., Candy, I., Drake, N., et al. (2009). The Cyrenaican Prehistory Project 2009: The third season of investigations of the Haua Fteah cave and its landscape, and further results from the 2007-2008 fieldwork. 
Libyan Studies, 40, 55-94.

Barker, G., Antoniadou, A., Armitage, S., Brooks, I., Candy, I., Connell, K., et al. (2010). The Cyrenaican Prehistory Project 2010: The fourth season of investigations of the Haua Fteah cave and its landscape, and further results from the 2007-2009 fieldwork. Libyan Studies, 41, 63-88.

Barton, N.E., Bouzouggar, A., Ramsey, C.B., Collcutt, S., Higham, T.F.G., Humphrey, L.T., et al. (2007). Abrupt climatic change and chronology of the Upper Palaeolithic in Northern and Eastern Morocco. In P. Mellars, K. Boyle, O. Bar-Yosef \& C. Stringer (Eds.), Rethinking the human revolution: New behavioural and biological perspectives on the origin and dispersal of modern humans (pp. 177-186). Cambridge: McDonald Institute for Archaeological Research.

Barton, R.N.E., Bouzouggar, A., Collcutt, S.N., Schwenninger, J.L., \& Clark-Balzan, L. (2009). OSL dating of the Aterian levels at Dar es-Soltan I (Rabat, Morocco) and implications for the dispersal of modern Homo sapiens. Quaternary Science Reviews, $28,1914-1931$.

Blackwell, B.A.B., Skinner, A.R., Mashriqi, F., Deely, A.E., Long, R.A., Gong, J.J.J., et al. (2012). Challenges in constraining pluvial events and hominin activity: Examples of ESR dating molluscs from the Western Desert, Egypt. Quaternary Geochronology, 10, 430-435.

Bouzouggar, A., Barton, N., Vanhaeren, M., d'Errico, F., Collcutt, S., Higham, T., et al. (2007). 82,000-year-old shell beads from North Africa and implications for the origins of modern human behavior. Proceedings of the National Academy of Sciences, 104(24), 9964-9969.

Chazan, M. (1995). Variability in the Middle Paleolithic of Haua Fteah, Libya. Paléorient, 21(1), 65-73. 
Churcher, C.S., Kleindienst, M.R., \& Schwarcz, H.P. (1999). Faunal remains from a Middle Pleistocene lacustrine marl in Dakhleh Oasis, Egypt: palaeoenvironmental reconstructions. Palaeogeography, Palaeoclimatology, Palaeoecology 154, 301-312.

Clark, J.D. (1992). African and Asian perspectives on the origins of modern humans. Philosophical Transactions: Biological Sciences, 337(1280), 201-215.

Close, A.E. (1986). The place of the Haua Fteah in the Late Palaeolithic of North Africa. In G. N. Bailey \& P. Callow (Eds.), Stone Age prehistory: Studies in memory of Charles McBurney (pp. 169-180). Cambridge: Cambridge University Press.

Close, A.E. (2002). Backed bladelets are a foreign country. Archeological Papers of the American Anthropological Association, 12(1), 31-44.

Cremaschi, M., Di Lernia, S., \& Garcea, E.A.A. (1998). Some insights on the Aterian in the Libyan Sahara: Chronology, environment, and archaeology. African Archaeological Review, 15(4), 261-286.

d'Errico, F., Vanhaeren, M., Barton, N., Bouzouggar, A., Mienis, H., Richter, D., et al. (2009). Additional evidence on the use of personal ornaments in the Middle Paleolithic of North Africa. Proceedings of the National Academy of Sciences, 106(38), 1605116056.

Drake, N. \& Breeze, P. (this volume). Climate change and modern human occupation of the Sahara from MIS 6-2. In S.C. Jones \& B.A. Stewart (Eds.), Africa from MIS 6-2: Population dynamics and paleoenvironments (pp.). New York: Springer.

Drake, N. A., El-Hawat, A.S., Turner, P., Armitage, S.J., Salem, M.J., White, K.H., et al. (2008). Palaeohydrology of the Fazzan Basin and surrounding regions: The last 7 million years. Palaeogeography, Palaeoclimatology, Palaeoecology, 263, 131-145.

Drake, N.A., Blench, R.M., Armitage, S.J., Bristow, C.S., \& White, K.H. (2011). Ancient watercourses and biogeography of the Sahara explain the peopling of the desert. 
Proceedings of the National Academy of Sciences, 108, 458-462.

Drake, N.A., Breeze, P., \& Parker, A. (2013). Paleoclimate in the Saharan and Arabian deserts during the Middle Paleolithic and the potential for hominin dispersals. Quaternary International, 300, 48-61.

Elfadli, K.I. (2009). Precipitation data of Libya. Tripoli: Climate Department, Libyan National Meteorological Center (LNMC).

Emiliani, C., \& McBurney, C.B.M. (1967). Palaeotemperature analysis by the oxygen isotope method at the Haua Fteah. In C.B.M. McBurney (Ed.), The Haua Fteah (Cyrenaica) and the Stone Age of the south-east Mediterranean (pp. 54-59). Cambridge: Cambridge University Press.

Garcea, E.A.A. (2010a). The spread of Aterian peoples in North Africa. In E. A. A. Garcea (Ed.), South-eastern Mediterranean peoples between 130,000 and 10,000 years ago (pp. 37-53). Oxford: Oxbow Books.

Garcea, E.A.A. (2010b). The Lower and Upper Late Stone Age of North Africa. In Southeastern Mediterranean peoples between 130,000 and 10,000 years ago (pp. 54-65). Oxford: Oxbow Books.

Garcea, E.A.A. (2010c). Bridging the gap between in and out of Africa. In E. A. A. Garcea (Ed.), South-eastern Mediterranean peoples between 130,000 and 10,000 years ago (pp. 174-181). Oxford: Oxbow Books.

Garcea, E.A.A. (2012a). Successes and failures of human dispersals from North Africa. Quaternary International, 270, 119-128.

Garcea, E.A.A. (2012b). Modern human desert adaptations: A Libyan perspective on the Aterian complex. In J.-J. Hublin \& S.P. McPherron (Eds.), Modern origins: A North African perspective (pp. 127-142). Dordrecht: Springer.

Garcea, E.A.A., \& Giraudi, C. (2006). Late Quaternary human settlement patterning in the 
Jebel Gharbi. Journal of Human Evolution, 51, 411-421.

Hawkins, A.L. (2012). The Aterian of the oases of the Western Desert of Egypt: Adaptation to changing climatic conditions? In J.-J. Hublin \& S.P. McPherron (Eds.), Modern origins: A North African perspective (pp. 157-175). Dordrecht: Springer.

Henrich, J. (2004). Demography and cultural evolution: How adaptive cultural processes can produce maladaptive losses - the Tasmanian case. American Antiquity, 69(2), 197-214.

Hey, R.W. (1968). The Quaternary geology of the Jabal al Akhdar coast. In F. T. Barr (Ed.), Geology and archaeology of northern Cyrenaica, Libya (pp. 159-165). Amsterdam: Petroleum Exploration Society of Libya.

Higgs, E. (1967). Environment and chronology: The evidence from mammalian fauna. In C.B.M. McBurney (Ed.), The Haua Fteah (Cyrenaica) and the Stone Age of the southeast Mediterranean (pp. 16-44). Cambridge: Cambridge University Press.

Hiscock, P. (1996). Transformations of Upper Palaeolithic implements in the Dabba industry from Haua Fteah (Libya). Antiquity, 70, 657-664.

Hublin, J.-J. (2001). Northwestern African Middle Pleistocene hominids and their bearing on the emergence of Homo sapiens. In L. Barham \& K. Robson-Brown (Eds.), Human roots. Africa and Asia in the Middle Pleistocene (Vol. 99-121). Bristol: CHERUB, Western Academic \& Specialist Press Ltd.

Hublin, J.-J., \& Klein, R.G. (2011). Northern Africa could also have housed the source population for living humans. Proceedings of the National Academy of Science, 108(28), E277.

Hublin, J.-J., \& McPherron, S.P. (Eds.). (2012). Modern origins: A North African perspective. Dordrecht: Springer.

Hunt, C., Davison, J., Inglis, R., Farr, L., Reynolds, T., Simpson, D., et al. (2010). Site formation processes in caves: The Holocene sediments of the Haua Fteah, Cyrenaica, 
Libya. Journal of Archaeological Science, 37(7), 1600-1611.

Hunt, C.O., Reynolds, T.G., El-Rishi, H.A., Buzaian, A., Hill, E., \& Barker, G.W. (2011). Resource pressure and environmental change on the North African littoral: Epipalaeolithic to Roman gastropods from Cyrenaica, Libya. Quaternary International, 244(1), 15-26.

Inglis, R.H. (2012). Human occupation and changing environments during the Middle to Later Stone Age: Soil micromorphology at the Haua Fteah, Libya. Ph.D. Dissertation, University of Cambridge.

Iovita, R.P. (2009). Reevaluating Connections between the early Upper Paleolithic of northeast Africa and the Levant: Technological differences between the Dabban and the Emiran. In J.J. Shea \& D.E. Lieberman (Eds.), Transitions in prehistory: Essays in honor of Ofer Bar-Yosef (pp. 125-142). Oxford: Oxbow Books.

Jones, S., Farr, L., Barton, H., Drake, N., White, K., \& Barker, G. (2011). Geoarchaeological patterns in the pre-desert and desert ecozones of northern Cyrenaica. Libyan Studies, 41, 89-97.

Klein, R.G., \& Scott, K. (1986). Re-analysis of faunal assemblages from the Haua Fteah and other Late Quaternary archaeological sites in Cyrenaican Libya. Journal of Archaeological Science, 13, 514-542.

Kleindienst, M.R. (2001). What is the Aterian? The view from Dakhleh Oasis and the Western Desert, Egypt. In C.A. Marlow \& A.J. Mills (Eds.), The Oasis Papers 1: The proceedings of the first conference of the Dakhleh Oasis Project (pp. 1-14). Oxford: Oxbow Books.

Lambeck, K., \& Purcell, A. (2005). Sea-level change in the Mediterranean Sea since the LGM: Model predictions for tectonically stable areas. Quaternary Science Reviews 24(18-19), 1969-1988. 
MacDonald, K.C. (1997). The avifauna of the Haua Fteah (Libya). Archaeozoologia, 9, 83102.

Macklin, M.G., Fuller, I.C., Lewin, J., Maas, G.S., Passmore, D.G., Rose, J., et al. (2002). Correlation of fluvial sequences in the Mediterranean basin over the last $200 \mathrm{ka}$ and their relationship to climate change. Quaternary Science Reviews, 21, 1633-1641.

Mattingly, D., Lahr, M., Armitage, S., Barton, H., Dore, J., Drake, N., et al. (2007). Desert migrations: People, environment and culture in the Libyan Sahara. Libyan Studies, 38, $1-42$.

McBrearty, S., \& Brooks, A. (2000). The revolution that wasn't: A new interpretation of the origin of modern human behaviour. Journal of Human Evolution, 39, 453-563.

McBurney, C.B.M. (1947). The Stone Age of the Libyan littoral: The results of a war-time reconnaissance. Proceedings of the Prehistoric Society, 13, 56-84.

McBurney, C.B.M. (1967). The Haua Fteah (Cyrenaica) and the Stone Age of the south-east Mediterranean. Cambridge: Cambridge University Press.

McBurney, C.B.M. (1968). Pleistocene and early post-Pleistocene archaeology of Libya. In F. T. Barr (Ed.), Geology and archaeology of northern Cyrenaica, Libya (pp. 13-21). Amsterdam: The Petroleum Exploration Society of Libya.

McBurney, C.B.M., \& Hey, R.W. (1955). Prehistory and Pleistocene geology in Cyrenaican Libya. Cambridge: Cambridge University Press.

McBurney, C.B.M., Hey, R.W., \& Watson, W. (1948). First report of the Cambridge archaeological expedition to Cyrenaica (1947). Proceedings of the Prehistoric Society, $14,33-45$.

McLaren, S.J. \& Reynolds, T. (2009). Early humans in dryland environments: A geoarchaeological perspective. In A.J. Parsons \& A. Abrahams (Eds.), Geomorphology of desert environments (pp. 773-798). Springer. 
Moyer, C. (2003). The organisation of lithic technology in the Middle and early Upper Palaeolithic industries at the Haua Fteah, Libya. Unpublished Ph.D. dissertation, University of Cambridge.

Olivieri, A., Achilli, A., Pala, M., Battaglia, V., Fornarino, S., Al-Zahery, N., et al. (2006). The mtDNA legacy of the Levantine early Upper Palaeolithic in Africa. Science, 314(5806), 1767-1770.

Osborne, A.H., Vance, D., Rohling, E.J., Barton, N., Rogerson, M., \& Fello, N. (2008). A humid corridor across the Sahara for the migration of early modern humans out of Africa 120,000 years ago. Proceedings of the National Academy of Science, 105(43), $16444-16447$.

Pereira, L., Silva, N., Franco-Duarte, R., Fernandes, V., Pereira, J., Costa, M., et al. (2010). Population expansion in the North African Late Pleistocene signalled by mitochondrial DNA haplogroup U6. BMC Evolutionary Biology, 10(1), 390.

Petrocchi, G. (1940). Ricerche preistoriche in Cirenaica. Africa Italiana, 7, 1-33.

Reynolds, T. (2013). The Middle Palaeolithic of Cyrenaica: Is there an Aterian at the Haua Fteah and does it matter? Quaternary International, 300, 171-181.

Richter, D., Moser, J., Nami, M., Eiwanger, J., \& Mikdad, A. (2010). New chronometric data from Ifri n'Ammar (Morocco) and the chronostratigraphy of the Middle Palaeolithic in the Western Maghreb. Journal of Human Evolution, 59(6), 672-679.

Rowan, J.S., Black, S., Macklin, M.G., Tabner, B.J., \& Dore, J. (2000). Quaternary environmental change in Cyrenaica evidenced by UTh, ESR and OSL of coastal alluvial fan sequences. Libyan Studies, 31, 5-16.

Sampson, C.G. (1967). Coarse granulometric analysis of the Haua Fteah deposits. In C. B. M. McBurney (Ed.), The Haua Fteah (Cyrenaica) and the Stone Age of the south-east Mediterranean (pp. 50-54). Cambridge: Cambridge University Press. 
Smith, J.R. (2010). Palaeoenvironments of eastern North Africa and the Levant in the late Pleistocene. In E.A.A. Garcea (Ed.), South-eastern Mediterranean peoples between 130,000 and 10,000 years ago (pp. 6-17). Oxford: Oxbow Books.

Smith, J.R. (2012). Spatial and temporal variation in the nature of Pleistocene pluvial phase environments across North Africa. In J.-J. Hublin \& S.P. McPherron (Eds.), Modern origins: A North African perspective (pp. 35-47). Dordrecht: Springer.

Smith, T.M., Tafforeau, P., Reid, D.J., Grün, R., Eggins, S., Boutakiout, M., et al. (2007). Earliest evidence of modern human life history in North African early Homo sapiens. Proceedings of the National Academy of Science, 104(15), 6128-6133.

Stringer, C., \& Barton, N. (2008). Putting North Africa on the map of modern human origins. Evolutionary Anthropology, 17, 5-7.

Van Peer, P. (1998). The Nile Corridor and the out of Africa model: An examination of the archaeological record. Current Anthropology, 39, S115-S140.

Van Peer, P. (this volume). Technological systems, population dynamics and historical process in the MSA of northern Africa. In S.C. Jones \& B.A. Stewart (Eds.), Africa from MIS 6-2: Population dynamics and paleoenvironments (pp.). New York: Springer.

Van Peer, P., \& Vermeersch, P.M. (2007). The place of northeast Africa in the early history of modern humans: New data and interpretations on the Middle Stone Age. In P. Mellars, K. Boyle, O. Bar-Yosef \& C. Stringer (Eds.), Rethinking the human revolution (pp. 187-198). Cambridge: McDonald Institute for Archaeological Research.

Vermeersch, P.M. (2010). Middle and Upper Palaeolithic in the Egyptian Nile Valley. In E.A.A. Garcea (Ed.), South-eastern Mediterranean peoples between 130,000 and 10,000 years ago (pp. 66-88). Oxford: Oxbow Books.

Wall-Scheffler, C.M. (2007). Digital cementum luminance analysis and the Haua Fteah 
hominins: How seasonality and season of use changed through time. Archaeometry, 49(4), 815-826.

Watson, W. (1949). The surface flint implements of Cyrenaica. Man, 49, 100-104.

Wendorf, F., \& Schild, R. (1992). The Middle Palaeolithic of North Africa: A status report. In F. Klees \& R. Kuper (Eds.), New light on the Northeast African past. (pp. 39-80). Köln: Heinrich Barth-Institut.

Wendorf, F., Close, A.E., \& Schild, R. (1987). Recent work on the Middle Palaeolithic of the Eastern Sahara. African Archaeological Review, 5, 49-63.

White, K., Charlton, M., Drake, N., McLaren, S., Mattingly, D., \& Brooks, N. (2006). Lakes of the Edeyen Ubari and the Wadi al-Hayat. In D. Mattingly, S. McLaren, E. Savage, Y. al-Fasatwi \& K. Gadgood (Eds.), The Libyan Desert: Natural resources and cultural heritage (pp. 123-130). London: The Society for Libyan Studies. 


\section{Tables}

Table 5.1. Site location data recorded during geoarchaeological survey of the different geographic clusters within the four biomes. Data includes site elevation, landforms upon which sites are located and frequency of chert sources recorded.

\begin{tabular}{|c|c|c|c|}
\hline Geographic cluster & $\begin{array}{l}\text { Number of sites } \\
\left(\text { elevation range }^{a}\right)\end{array}$ & $\begin{array}{l}\text { Landforms } \\
\text { (no. of sites) }\end{array}$ & $\begin{array}{l}\text { Chert } \\
\text { source }^{b}\end{array}$ \\
\hline \multicolumn{4}{|l|}{ DESERT } \\
\hline Baltat lawlah al Halq (west) & $5(120-140 m)$ & paleolake (3); hill slope (1); hill top (1) & 1 \\
\hline Baltat lawlah al Halq (east) & $3(120-127 m)$ & paleolake (2); wadi channel (1) & 0 \\
\hline \multicolumn{4}{|l|}{ PRE-DESERT } \\
\hline Baltat ar Ramlah (east) & $20(128-144 m)$ & $\begin{array}{l}\text { alluvial fan (9); hill slope (1); paleolake (8); } \\
\text { paleolake island (1); plateau (1) }\end{array}$ & 2 \\
\hline Baltat ar Ramlah (west) & $3(128-138 m)$ & hill slope (1); hill top (1); paleolake island (1) & 1 \\
\hline Wadi al Hammam & $2(231-233 m)$ & alluvial fan (2) & 1 \\
\hline Wadi Ramlah & $3(277-284 m)$ & plain (2); wadi terrace (1) & 0 \\
\hline Wadi Samalus & $12(262-281 \mathrm{~m})$ & hill slope (8); hill top (3); slope base (1) & 6 \\
\hline Wadi Tanamlu & $4(217-328 m)$ & alluvial fan (3); plateau (1) & 0 \\
\hline \multicolumn{4}{|l|}{ GEBEL AKHDAR } \\
\hline Al-Marj canal & $37(249-289 m)$ & basin (37) & 1 \\
\hline Haua Fteah hinterland & $13(108-225 \mathrm{~m})$ & $\begin{array}{l}\text { hill slope (7); hilltop (4); plateau (1); wadi } \\
\text { channel (1) }\end{array}$ & 6 \\
\hline North Gebel (Lamludah north) & $17(241-653 m)$ & $\begin{array}{l}\text { hill slope (5); hilltop (4); plateau (3); tufa dam } \\
\text { (1); wadi channel (2); wadi terrace (1); slope base } \\
\text { (1) }\end{array}$ & 2 \\
\hline South Gebel & $1(459 m)$ & plain (1) & 0 \\
\hline Upper Gebel (Lamludah south) & $8(624-802 m)$ & hill slope (4); wadi channel (3); wadi terrace (1) & 0 \\
\hline Wadi Derna & $6(90-146 m)$ & hill slope (2); wadi channel (3); wadi terrace (1) & 0 \\
\hline Wadi Kuf Gebel & $3(341-367 m)$ & cave (3) & 0 \\
\hline \multicolumn{4}{|l|}{ LITTORAL } \\
\hline Chersa & $10(0-18 m)$ & coastal terrace $(10)$ & 0 \\
\hline El Atrun & $7(5-6 m)$ & coastal terrace $(7)$ & 0 \\
\hline Haua Fteah littoral & $19(10-75 \mathrm{~m})$ & $\begin{array}{l}\text { cave (1); coastal terrace (10); hill slope (2); hill } \\
\text { top (1); slope base }(2) \text {; wadi channel (1); wadi } \\
\text { terrace (2) }\end{array}$ & 0 \\
\hline Ras al Hillal & $3(8-13 m)$ & coastal terrace (3) & 0 \\
\hline Wadi Gladia littoral & $3(7-87 \mathrm{~m})$ & coastal terrace (2); hill slope (1) & 0 \\
\hline Wadi Kuf littoral & $2(1-14 m)$ & cave $(1)$; coastal terrace $(1)$ & 0 \\
\hline
\end{tabular}


Table 5.2. Archaeological data collected during geoarchaeological survey of the different geographic clusters within the four biomes, including the frequency of MSA sites, LSA sites, sites preserving both MSA and LSA material and sites preserving undiagnostic lithics. Particular types of lithic artifacts encountered in each geographic cluster are provided. Further details regarding the lithic technologies found in some of these geographic clusters are available elsewhere (Barker et al. 2009, 2010; Jones et al. 2011).

\begin{tabular}{|c|c|c|c|c|}
\hline $\begin{array}{l}\text { Geographic } \\
\text { cluster }\end{array}$ & $\begin{array}{l}\text { Paleolithic } \\
\text { phase(s) }\end{array}$ & $\begin{array}{l}\text { Number } \\
\text { of sites }\end{array}$ & Site Identification numbers & $\begin{array}{l}\text { Examples of lithic } \\
\text { technologies present }\end{array}$ \\
\hline \multicolumn{5}{|l|}{ DESERT } \\
\hline \multirow{3}{*}{$\begin{array}{l}\text { Baltat lawlah al } \\
\text { Halq (west) }\end{array}$} & MSA & 3 & $8049,8050,8053$ & Levallois, discoidal \\
\hline & MSA \& LSA & 1 & 8054 & Discoidal, blade, microblade \\
\hline & LSA & 1 & 8051 & Blade \\
\hline \multirow{2}{*}{$\begin{array}{l}\text { Baltat lawlah al } \\
\text { Halq (east) }\end{array}$} & MSA & 2 & 8056,8057 & Discoidal \\
\hline & LSA & 1 & 8055 & \\
\hline \multicolumn{5}{|l|}{ PRE-DESERT } \\
\hline \multirow[t]{4}{*}{$\begin{array}{l}\text { Baltat ar Ramlah } \\
\text { (east) }\end{array}$} & MSA & 13 & $\begin{array}{l}8007,8009,8010,8011,8012, \\
8013,8014,8025,8059,8060, \\
8061,8062,8063\end{array}$ & $\begin{array}{l}\text { Levallois, discoidal, bifacial, } \\
\text { tanged }\end{array}$ \\
\hline & MSA \& LSA & 1 & 8021 & Levallois \\
\hline & LSA & 2 & 8015,8024 & Blade, bladelet \\
\hline & Unknown & 4 & $8008,8017,8023,8058$ & \\
\hline \multirow{2}{*}{$\begin{array}{l}\text { Baltat ar Ramlah } \\
\text { (west) }\end{array}$} & MSA \& LSA & 2 & 8026,8027 & Discoidal, bladelet \\
\hline & LSA & 1 & 8028 & Blade, bladelet, backed \\
\hline \multirow{4}{*}{$\begin{array}{l}\text { Wadi al } \\
\text { Hammam } \\
\text { Wadi Ramlah }\end{array}$} & MSA & 2 & 8043,8044 & Discoidal \\
\hline & MSA & 1 & 8003 & Bifacial \\
\hline & MSA \& LSA & 1 & 8004 & \\
\hline & Unknown & 1 & 8005 & \\
\hline \multirow[t]{4}{*}{ Wadi Samalus } & MSA & 3 & $8029,8031,8034$ & Levallois, discoidal \\
\hline & MSA \& LSA & 4 & $8032,8033,8035,8038$ & $\begin{array}{l}\text { Levallois, discoidal, bifacial, } \\
\text { blade, bladelet, backed }\end{array}$ \\
\hline & LSA & 4 & $8037,8040,8041,8042$ & Blade, bladelet \\
\hline & Unknown & 1 & 8030 & \\
\hline Wadi Tanamlu & MSA & 4 & $8045,8046,8047,8048$ & Levallois, discoidal \\
\hline \multicolumn{5}{|l|}{$\begin{array}{l}\text { GEBEL } \\
\text { AKHDAR }\end{array}$} \\
\hline \multirow[t]{2}{*}{ Al-Marj canal } & MSA & 33 & $\begin{array}{l}\text { EM: } 3,4,9,10,11,17,18,20, \\
21,101,102,103,105,106,107, \\
109,110,113,114,117,119,120 \text {, } \\
121-131\end{array}$ & $\begin{array}{l}\text { Levallois, discoidal, handaxe, } \\
\text { bifacial, stemmed, tanged, } \\
\text { blade, bladelet }\end{array}$ \\
\hline & Unknown & 4 & EM: $111,112,116,118$ & \\
\hline \multirow{3}{*}{$\begin{array}{l}\text { Haua Fteah } \\
\text { hinterland }\end{array}$} & MSA & 1 & 2020 & \\
\hline & LSA & 1 & 8069 & Blade, bladelet \\
\hline & Unknown & 11 & $1013,1016,2004,2005,2006$ & \\
\hline
\end{tabular}


2007, 2009, 2011, 2012, 2013

2016

$\begin{array}{llll}\text { North Gebel } & \text { MSA } & 1 & 8120\end{array}$

MSA \& LSA 1

$\begin{array}{llll} & \text { LSA } & 9 & 8100,8102,8103,8104,8107, \\ & & & 8111,8116,8117,8118 \\ & \text { Unknown } & 6 & 8101,8105,8106,8108,8109, \\ & & & 8110 \\ \text { South Gebel } & \text { Unknown } & 1 & 8000 \\ \text { Upper Gebel } & \text { LSA } & 6 & 8064,8065,8066,8068,8112, \\ & & & 8113 \\ & & & 8114,8115 \\ \text { Wadi Derna } & \text { Unknown } & 2 & 1825 \mathrm{a} \text { (Hajj Creiem), } 1846\end{array}$

1817

LSA

Unknown 3

$1815,1816,2021$

Wadi Kuf Gebel

LSA

1647 (Hagfet ed Dabba)

\section{Unknown $2 \quad 1639,1642$}

Levallois

Levallois blade, truncatedfaceted, carinated endscraper, bladelet, backed Bifacial point, chamfered blade, bladelet, backed

Discoidal, blade, bladelet, backed, bifacial point, carinated endscraper

see McBurney and Hey (1955) for Hajj Creiem technologies

Bladelet

See, e.g., McBurney and Hey (1955) for Hagfet ed Dabba technologies

\begin{tabular}{|c|c|c|c|c|}
\hline \multicolumn{5}{|l|}{ LITTORAL } \\
\hline \multirow[t]{3}{*}{ Chersa } & MSA & 8 & $\begin{array}{l}1830,1831,1832 b, 1835,1837, \\
1838,1848,1851\end{array}$ & Levallois \\
\hline & LSA & 1 & 1834 & Backed \\
\hline & Unknown & 1 & 1849 & Blade \\
\hline \multirow[t]{3}{*}{ El Atrun } & MSA & 5 & $1801,1802,1803,1805,1823$ & Levallois \\
\hline & LSA & 1 & 1800 & Bladelet \\
\hline & Unknown & 1 & 1798 & \\
\hline \multirow{4}{*}{$\begin{array}{l}\text { Haua Fteah } \\
\text { littoral }\end{array}$} & MSA & 2 & 1008,2002 & Levallois, bifacial \\
\hline & MSA \& LSA & 2 & Haua Fteah, 1826 & $\begin{array}{l}\text { See, e.g., McBurney (1967) } \\
\text { for Haua Fteah technologies }\end{array}$ \\
\hline & LSA & 2 & 1006,1529 & Blade, bladelet \\
\hline & Unknown & 13 & $\begin{array}{l}\text { 1000, 1001, 1002, 1003, 1004, } \\
1005,1007,1009,1010,1011, \\
2017,2018,2019\end{array}$ & \\
\hline \multirow[t]{2}{*}{ Ras al Hillal } & MSA \& LSA & 1 & 1818 & Blade, bifacial point \\
\hline & Unknown & 2 & 1792,1794 & \\
\hline \multirow[t]{3}{*}{ Wadi Gladia } & MSA \& LSA & 1 & $1571 \mathrm{a}$ & \\
\hline & LSA & 1 & 1827 & Bladelet, backed \\
\hline & Unknown & 1 & $1571 b$ & \\
\hline \multirow[t]{2}{*}{$\begin{array}{l}\text { Wadi Kuf } \\
\text { littoral }\end{array}$} & LSA & 1 & 2008 (Hagfet al-Gama) & $\begin{array}{l}\text { Bladelet, backed (Capsian) } \\
\text { (Barker et al. 2008) }\end{array}$ \\
\hline & Unknown & 1 & 1813 & \\
\hline
\end{tabular}

a "Unknown" refers to sites preserving lithic artifacts that cannot be assigned to either the Middle Stone Age or Late Stone Age (i.e., at sites where only a small number of lithics are present and/or there are no artifacts present that are typologically or technologically diagnostic). 


\section{Figure captions}

Fig. 5.1. Landsat satellite map showing the distribution of Paleolithic sites in the TRANSNAP study area, divided into the four ecological zones: littoral, upland Gebel Akhdar, predesert and desert. Key sites mentioned in the text are indicated and the inset shows where the surveyed area is situated in North Africa.

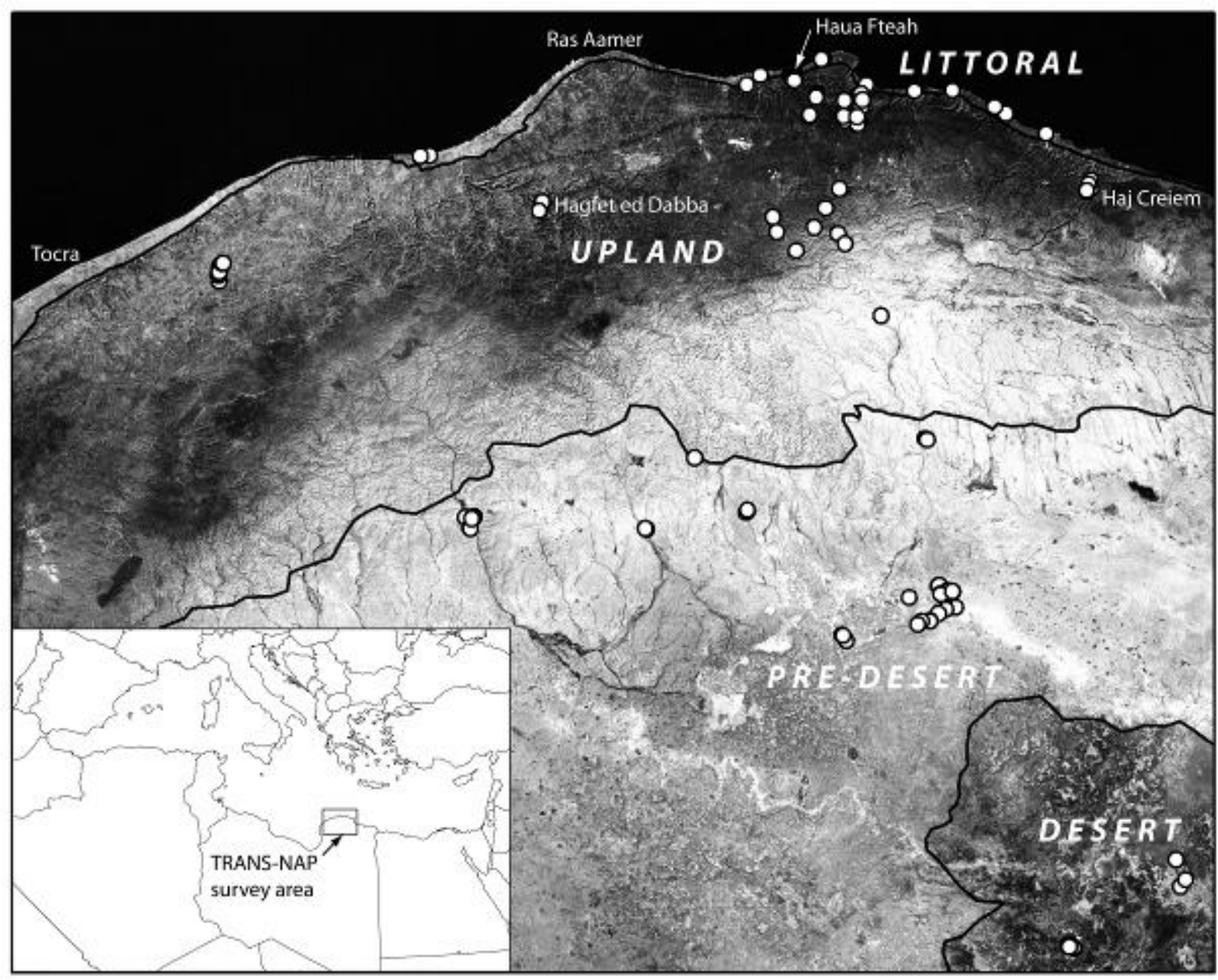


Fig. 5.2. Geographic clusters of Paleolithic sites in the TRANS-NAP study area according to elevation.
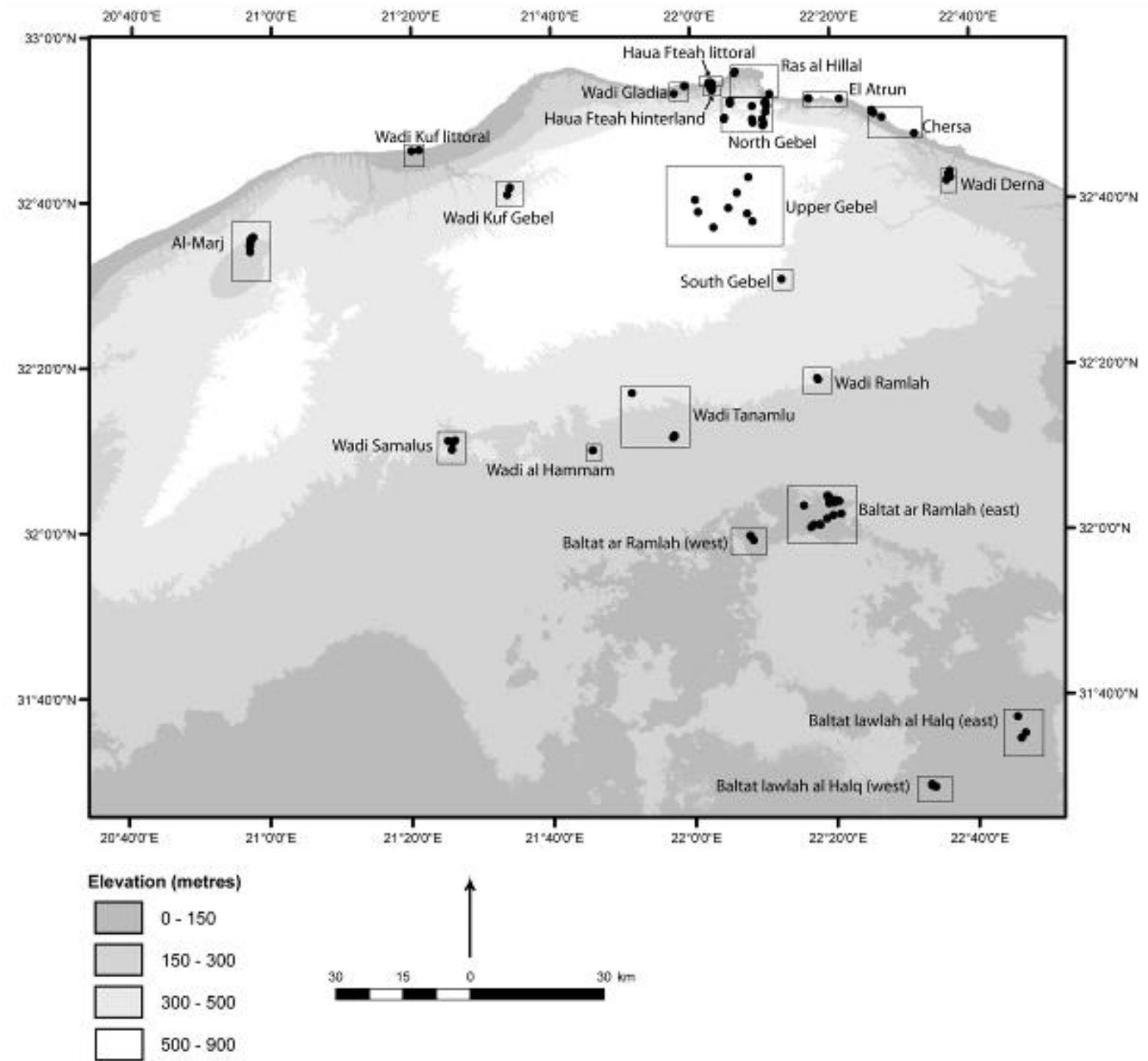
Fig. 5.3. Examples of MSA and LSA lithic artifacts recovered during surveys in seven of the geographic clusters depicted in Fig. 5.2 (clockwise from top left): (1) MSA artifacts from AlMarj (Levallois and discoidal cores, handaxe); (2) LSA artifacts from the North Gebel cluster (bladelet core, chamfered blade, bifacial foliate, backed bladelet fragment); (3) LSA artifacts from the Upper Gebel (bidirectional core, side-retouched blade, bladelet fragment); (4) artifacts from MSA and LSA sites in Baltat ar Ramlah (west) (crested blade, flakes); (5) blade from LSA site in Baltat lawlah al Halq (west); (6) multiplatform core from probable LSA site in Wadi Samalus; (7) predominantly MSA artifacts from Baltat ar Ramlah (east) (Levallois, discoidal and bifacial cores, flakes, blades).

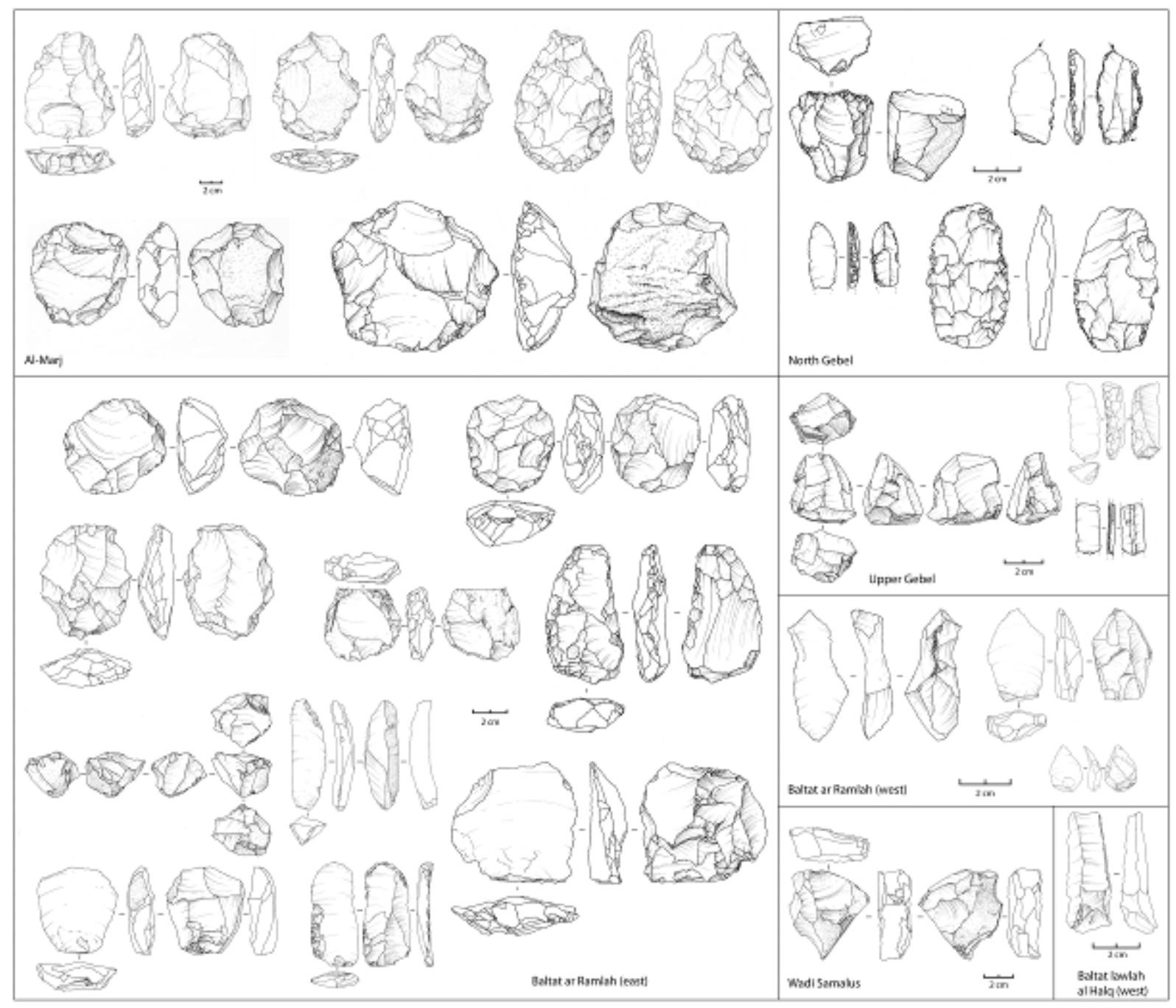


Fig. 5.4. Distribution of chert sources, MSA sites, LSA sites and sites preserving both MSA and LSA artifacts in geographic clusters (see Fig. 5.2) located in the northern half of the study region.
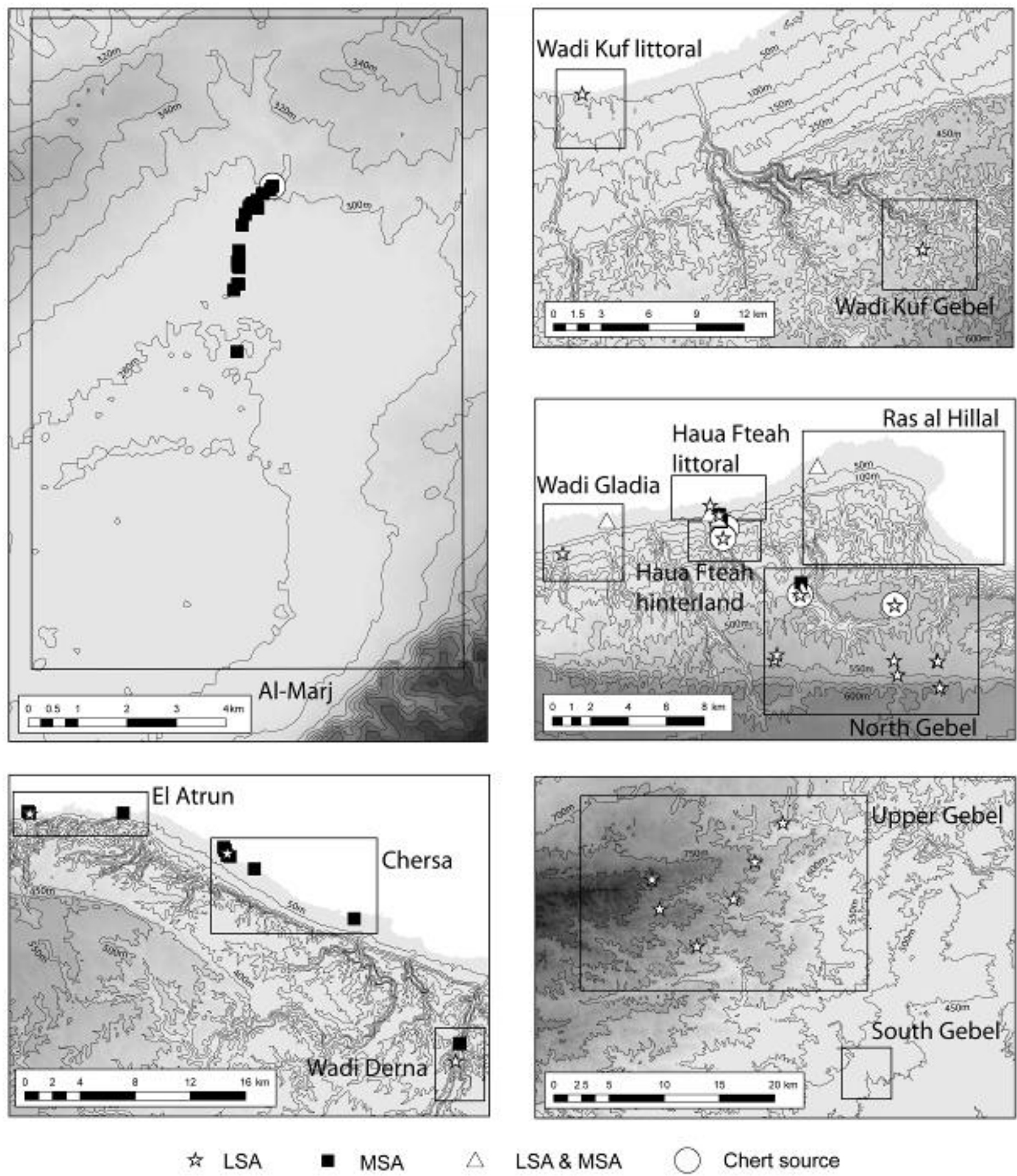

LA \& MSA $\bigcirc$ Chert source 
Fig. 5.5. Distribution of chert sources, MSA sites, LSA sites and sites preserving both MSA and LSA artifacts in geographic clusters (see Fig. 5.2) located in the southern half of the study region.
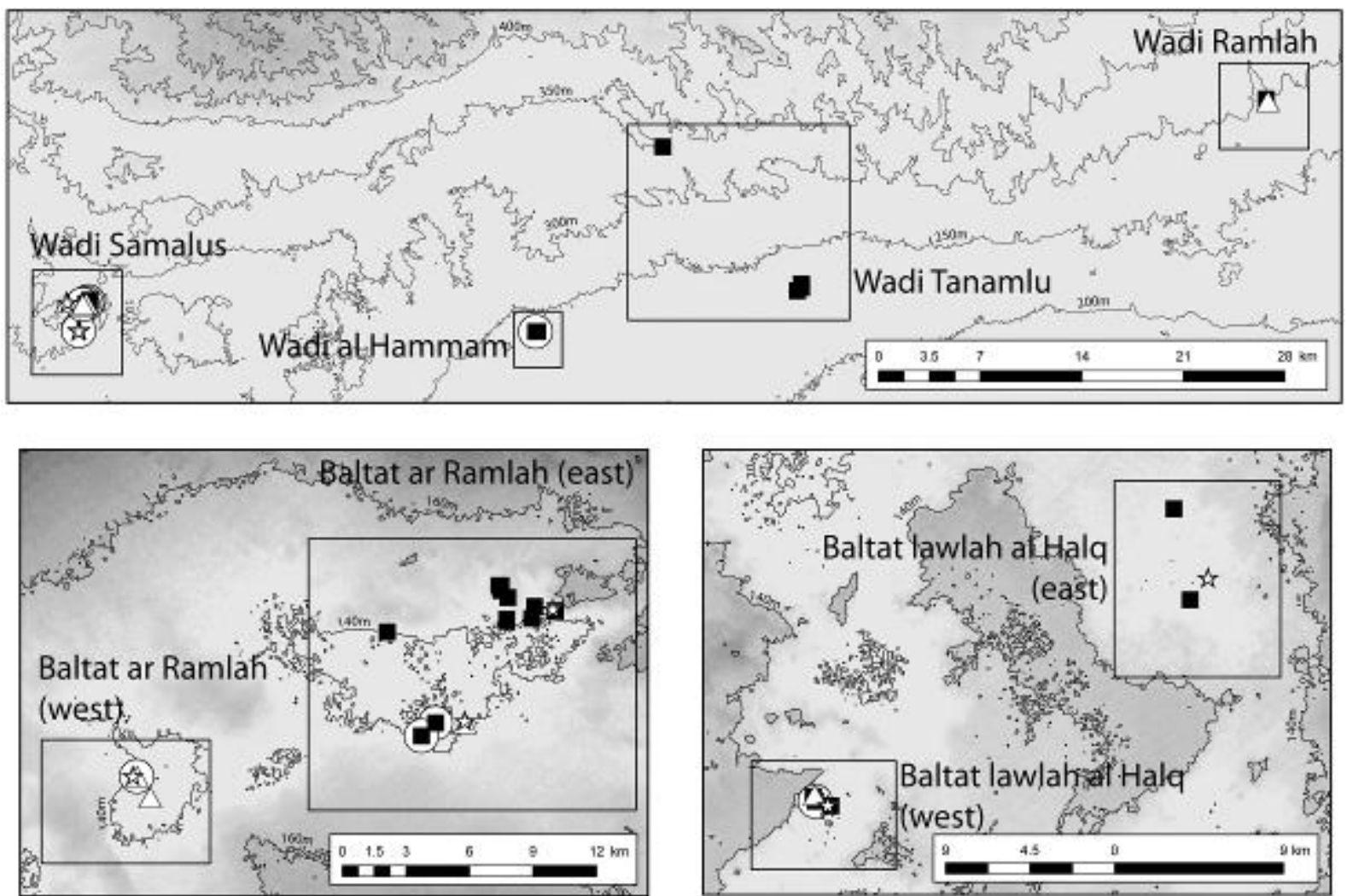

if LSA

- MSA

$\triangle \quad$ LSA \& MSA

Chert source 
Fig. 5.6. Scatterplot depicting the distribution of sites with MSA, LSA and both MSA and LSA artifacts according to site elevation and geographic cluster.

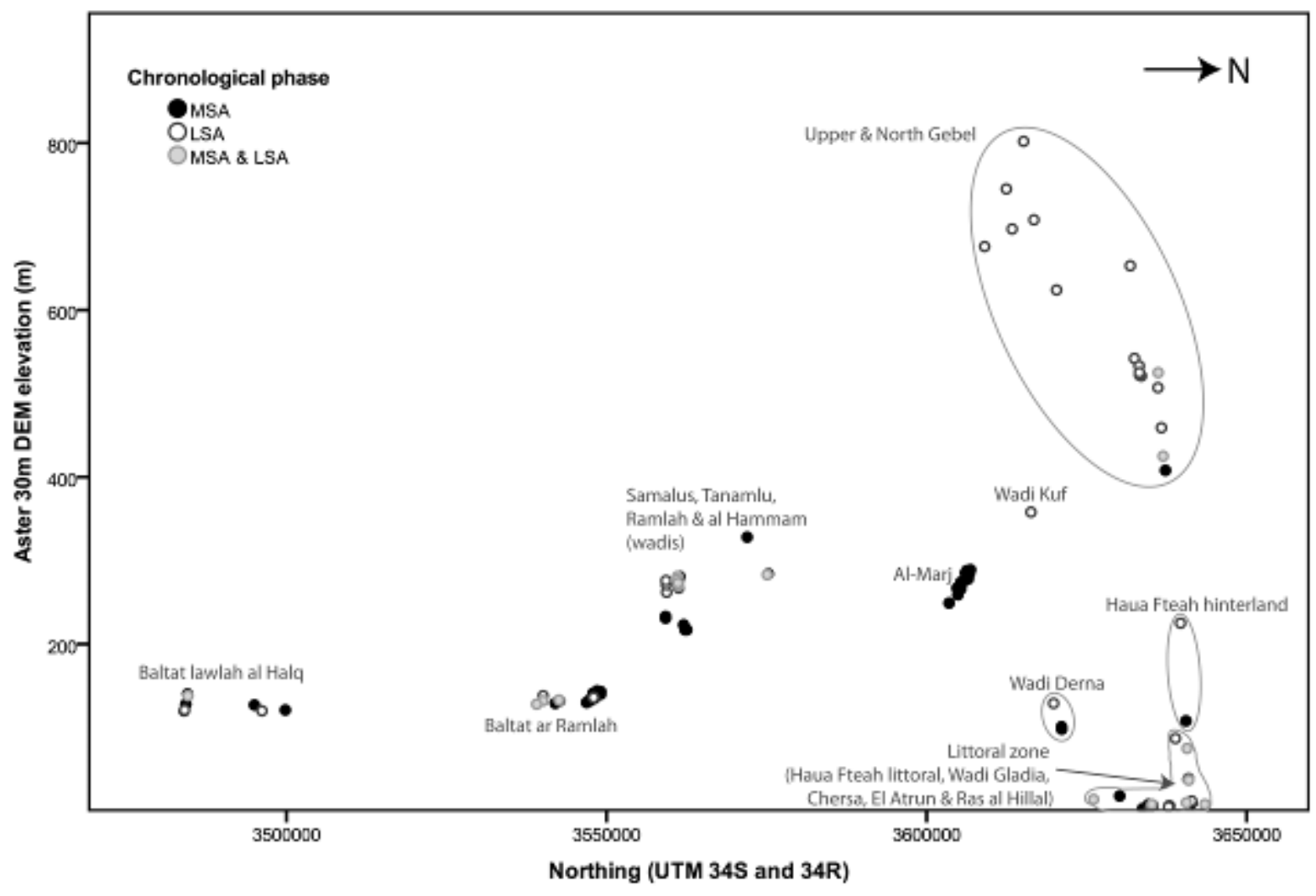


Fig. 5.7. (a) Late Pleistocene and early Holocene paleohydrology of the Sahara (c. 11 to 8 ka) developed from Drake et al. (2011). The 200-mm isohyet indicates the current limit of the Sahara Desert. (b) Area enlarged in Fig. 5.8.

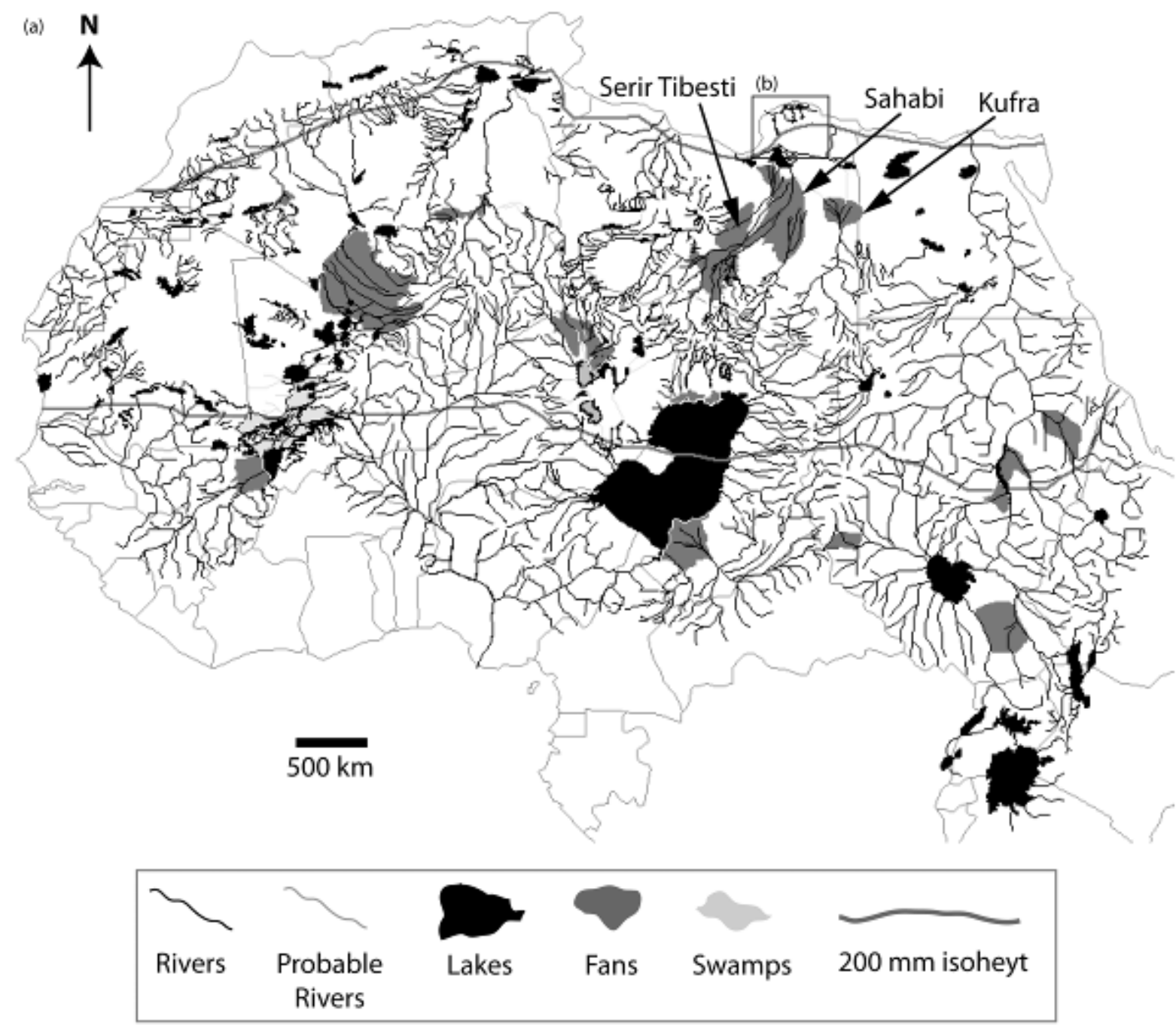


Fig. 5.8. Late Pleistocene and early Holocene (c. 11 to $8 \mathrm{ka}$ ) paleohydrology of Cyrenaica and the northern Sahara developed using the methods described by Drake et al. (2011). See Fig. 5.7 for the location of the mapped area in North Africa.

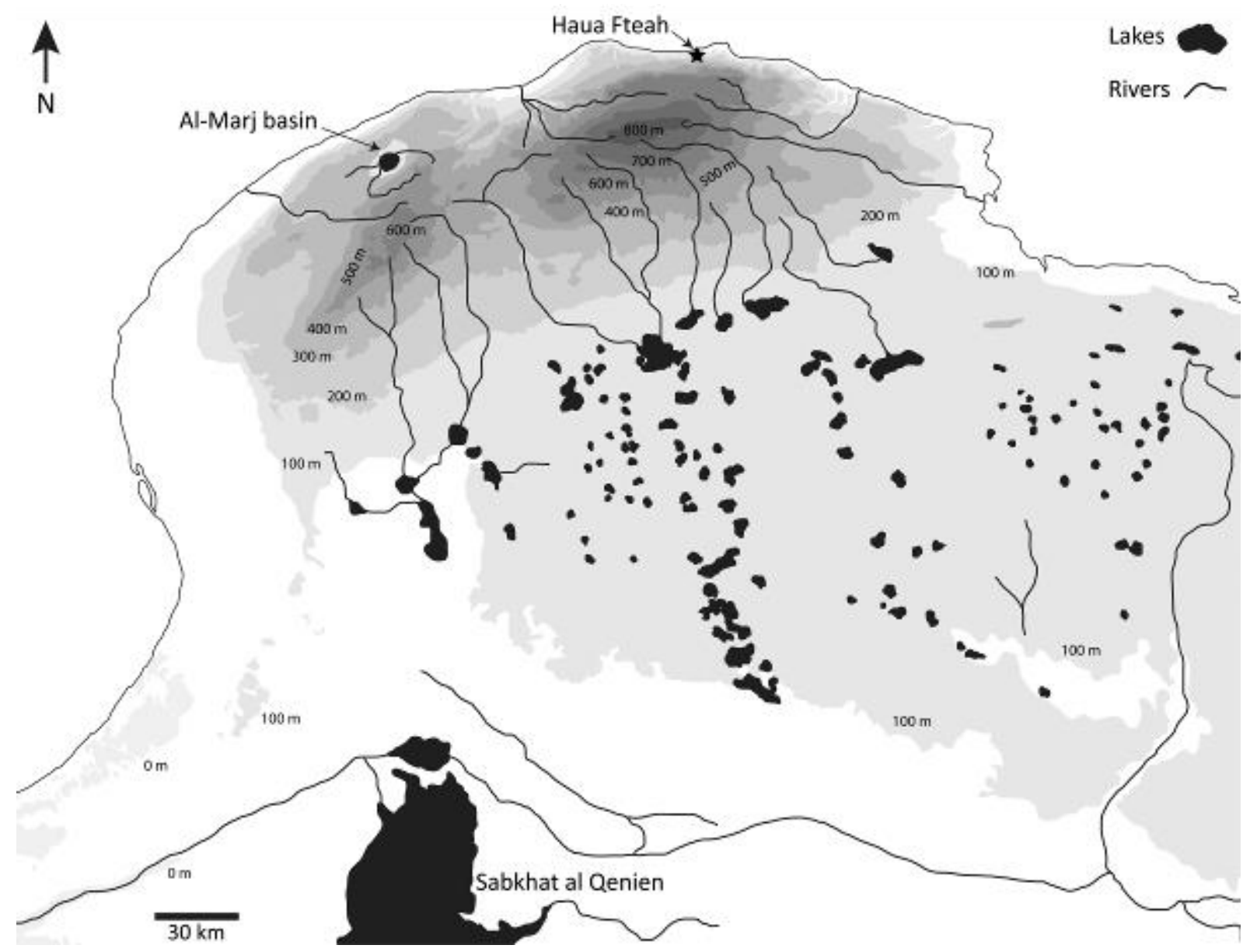

